\title{
Activated Carbon Impregnated by Zero-Valent Iron Nanoparticles (AC/nZVI) Optimized for Simultaneous Adsorption Furfural: Green Synthesis, Regeneration, Characterization, and Adsorption- Desorption Studies
}

\section{Yousef Rashtbari}

Arabil University of Medical Sciences

Shirin Afshin

Ardabil University of Medical Sciences

Asghar Hamzezadeh

Ardabil University of Medical Sciences

\section{Soumya Ghosh}

University of the Free State Faculty of Natural and Agricultural Sciences

\section{Ayoob Rastegar}

Sabzevar University of Medical Sciences

Yousef Poureshgh ( $\nabla$ yusef.poureshg@gmail.com )

Ardabil University of Medical Sciences: Ardebil University of Medical Sciences https://orcid.org/00000002-1573-2744

\section{Shahin Ahmadi}

Zabol University of Medical Sciences

Farooq Sher

Environmental and computing,Coventry University

\section{Research Article}

Keywords: Environmental pollutants. Green synthesis. nanoparticles. furfural adsorption. activated carbon. nZVI

Posted Date: April 16th, 2021

DOI: https://doi.org/10.21203/rs.3.rs-312106/v1

License: (9) This work is licensed under a Creative Commons Attribution 4.0 International License. Read Full License 



\section{Abstract}

35 Furfural is an organic aromatic compound that has attracted considerable interest as a potential

36 chemical for the production of biochemical and biofuels. However, furfural has proved to 37

\section{Activated carbon impregnated by zero-valent iron nanoparticles (AC/nZVI) optimized for simultaneous adsorption furfural: Green synthesis, regeneration, characterization, and adsorption-desorption studies}

${ }^{1}$ Department of Environmental Health Engineering, School of Health, Ardabil University of Medical Sciences, Ardabil, Iran

${ }^{2}$ Department of Genetics, Faculty of Natural and Agricultural Sciences, University of the Free State, Bloemfontein 9300, South Africa

${ }^{3}$ Department of Environmental Health Engineering, School of Public Health, Sabzevar University of Medical Sciences, Sabzevar, Iran

${ }^{4}$ Department of Environmental Health, Zabol University of Medical Sciences, Zabol, Iran

${ }^{5}$ School of Mechanical, Aerospace and Automotive Engineering, Faculty of Engineering, Environmental and Computing, Coventry University, Coventry CV1 5FB, United Kingdom

\section{*Corresponding authors:}

\section{Dr Yousef Poureshgh}

Department of Environmental Health Engineering, School of Health, Ardabil University of Medical Sciences, Ardabil, Iran

Email: yusef.poureshg@gmail.com

Dr Shahin Ahmadi

Department of Environmental Health, Zabol University of Medical Sciences, Zabol, Iran

Email:sh.ahmadi398@gmail.com possess ecotoxic effect on the environment and to humans, therefore measures are required to 
prevent these effects. One of the most widely used methods for eliminating furfural is the surface adsorption process. The present study focused on the structure and morphology of the composite nanoparticles, investigated using FTIR, XRD, BET and FE-SEM techniques.Furthermore, the variables of time, solution $\mathrm{pH}$, dosage composite and initial furfural were evaluated. Furfural adsorption was performed by spectrophotometer at a wavelength of $227 \mathrm{~nm}$. The removal efficiency under optimal conditions for furfural (Furfural concentration of $250 \mathrm{mg} / \mathrm{L}$, the composite dose of $4 \mathrm{~g} / \mathrm{L}$, the reaction time of $60 \mathrm{~min}$ and $\mathrm{pH}=7$ ) was $81.46 \%$. In addition, the study of isotherm and adsorption kinetics for furfural showed that the adsorption process follows the Langmuir isotherm and quasi-quadratic kinetics. The $\mathrm{q}_{\max }$ of the composite was determined by the Langmuir model of $222.22 \mathrm{mg} / \mathrm{g}$. Therefore, the present study exclusively showedthat the activated carbon coated with nZVI nanoparticles used as an effective and environmentally friendly adsorbent for furfural removal from aqueous solutions. Furthermore, this study could possiblyhave applied for the adsorbtion of other chemical cmpounds such as dyes,metronidazole, aniline.

Keywords Environmental pollutants. Green synthesis. nanoparticles. furfural adsorption. activated carbon. nZVI

\section{Introduction}

The presence of resistant and toxic materials and substances in water sources that can cause complexproblems(USEPA 1998). Complex chemical compounds of various industries such as petrochemicals, oil refineries, process units and chemical production have entered the environment and these industries have always been considered as a major source of environmental pollutants, especially soil and water resources. Among the wide range of elements present in the environment, furfural is used on a large scale in refineries and petrochemical industries, paper and cardboard, oil refining and is present in their wastewater in the range of 100-1200 mg/L(Borghei \&Hosseini 2008, Elaheh et al. 2011, Hoydonckx et al. 2000, Li et al. 2011, Shu 2006, Singh et al. 2009, Yang et al. 2012). Furfural is one of the types of aromatic aldehydes. Furfural is a bi-furfural liquid and oil that has an almond odour and rapidly turns to

67 yellow furfural upon contact with air (OSHA. Washington 1992). Furfural is soluble in water and has a boiling point of $161.8{ }^{\circ} \mathrm{C}$ (EPA 2006, Zeitsch 2000). Human exposure can occur

69 through inhalation, swallowing, skin or eye contact, or absorption through the skin. Exposure to

70 concentrations of 1.9-14ppm from furfural has caused headaches, redness of the eyes, and tearing 
71 in some workers exposed to it. Exposure to higher concentrations causes pulmonary

72 edema(Anbia \&Mohammadi 2009, Faramarzpour et al. 2009, OSHA. Washington 1992).

73 Several methods have been studied in furfural removal, the most important of which are

74 biological methods and adsorption process. Catalytic and photocatalytic methods, extraction

75 from nanofiltration solvents are other methods that have been studied and reported by various

76 researchers in furfural removal (Anbia \&Mohammadi 2009, Faramarzpour et al. 2009, Mao et al.

77 2012, Singh et al. 2009, Zhang et al. 2011). Studies have shown that the furfural biodegradation

78 includes both aerobic and anaerobic approaches, which are expensive. Furthermore, under the

79 influence of various parameters and toxicity of furfural at high concentrations, as well as

80 difficulties in degradability and toxicity of most compounds in the petrochemical industry

81 effluent, the use of this method has made furfural removal practically impossible(Fahmi et al.

82 2011, Mebrek \&Derriche 2010, Sahu et al. 2008).Other advantages of this methodare production

83 and high-quality effluents (Iram et al. 2010, Shen et al. 2011).

84 Nanotechnology is the study of the materials that are $<100 \mathrm{~nm}$ in size, and their physical,

85 chemical and biological properties are fundamentally different from their origin. Multiple

86 methods have been proposed so far for the synthesisofnanoparticles (Shen et al. 2011). Many of

87 these methods are not efficient enough (Iram et al. 2010). A chemical reducing agent (e.g.

88 sodium borohydride) is efficiency metal ions and a stabilizing agent (e.g., polyvinylpyrrolidone)

89 is used to control the growth of particles and prevent them from accumulating(Fazlzadeh et al.

90 2017). Several methods are environmental friendly as well(Ramezani et al. 2013). However,

91 there is a considerable interest in the biosynthesis of metal nanoparticles using organisms such as

92 plant and microbial extracts (Iram et al. 2010). Among these organisms, plant extract synthesis

93 or the green synthesis of nanoparticles have been prioritized because of the stability imparted to

94 the nanoparticles.

95 During the green synthesis, a redox reaction occurs in the saline solutions in which the plant

96 extracts (reducing agents) transfer electrons to metal ions and eventually metal nanoparticles are

97 produced. In this method, no pressure, energy, high temperature and toxic chemicals are

98 involved, therefore, pose lower risks to humans and ecosystems and is cost-effective (Fazlzadeh

99 et al. 2017).Today, materials nature (plant extracts) such as grape residue, grapefruit and

100 eucalyptus leaves, black tea extract, have been used to synthesize nZVInanoparticles (Fazlzadeh

101 et al. 2017, Ramezani et al. 2013). Recently, accelerate the separation of nanomaterials from 
102 aqueous media to stabilize nanoparticles on materials such as oxides, polymers, Fibers, activated 103 carbon, etc. are required. Among the above, the use of passive carbon has driven economic 104 benefits and environmental considerations (Fazlzadeh et al. 2017, Ghaedi et al. 2013).

105 Activated carbon has high availability, low cost, high surface area, reusability, properties of 106 surface chemistry and high pore volume and therefore has involvedenormous 107 consideration(Bhatia et al. 2018). However, commercial activated carbon(AC)has been proved 108 expensive. Therefore, there is an essence for economically affordable materials that could be an 109 alternative for the commercially available activated carbon.At the other end,AC can be obtained 110 extensively from materials such as Algae, coconut shell, corn, lignin, etc(Mohan \&Pittman 111 2006).However, there are limited studies that have reported on the performance of AC prepared 112 from pomegranate peel and the stabilization effect of nanoparticles using plant extracts on 113 activated carbon for furfural removal, evaluation of its efficiency in the removal under the 114 influence of various variables on the process such as $\mathrm{pH}$, reaction time, adsorbent dose and initial 115 furfural concentration in synthetic solutions. Therefore, the present study has assessed the use of 116 activated carbon prepared from the pomegranate peels coated with nZVI nanoparticles, as an 117 effective and ecologically friendly adsorbent for furfural elimination from aqueous solutions.

\section{Materials and methods}

\section{Material}

120 The furfural (Chemical formula: $\mathrm{C}_{5} \mathrm{H}_{4} \mathrm{O}_{2}$ and Molecular weight: $96.08 \mathrm{~g} / \mathrm{mol}$ ) and all the 121 chemicals such as $\mathrm{a}_{2} \mathrm{SO}_{4}$ and $\mathrm{NaOHwere}$ procured from Merck, Germany. $\mathrm{H}_{2} \mathrm{SO}_{4}$ and $\mathrm{NaOH}$ 122 were to adjust the $\mathrm{pH}$ of the furfural solution. The water was used twice in all stages of the 123 experiments.

\section{Characterization of the furfural}

125 The specific surface area was determined based on BET analysis and pore volume by nitrogen 126 gas adsorption analysis. The average diameter of the cavities and the total volume of the cavities 127 were also determined. The surface structure of the adsorbent was analyzed by field emission 128 scanning electron microscopy (FESEM) at the same magnification. FTIR analysis in the range of $129450-4000 \mathrm{~cm}^{-1}$ was used to identify the functional groups on the nanocomposite surface by 130 Perkin Elmer Spectrum Two. X-ray diffraction of the composite was determined at an angle in 
131 the range of $2 \theta=10-80$ by XRD (Philips PNA-analytical diffractometer). The residual furfural

132 concentration was measured by DR5000HACH spectrophotometer at $277 \mathrm{~nm}$ (Singh et al. 2009).

133 Preparation of the active carbon

134 In this study, pomegranate peel was used to prepare activated carbon. In the first stage, the 135 pomegranate skin was sliced into $0.5 \mathrm{~cm}$ pieces and impregnated with phosphoric acid. The 136 impregnated skins were transferred to the reactor and placed at $800{ }^{\circ} \mathrm{C}$ for $2 \mathrm{~h}$. Following the 137 removal from the reactor, the carbon was rinsed with distilled water and placed in an oven at $138110^{\circ} \mathrm{C}$ for $2 \mathrm{~h}$ to dry. Finally, AC was separated by a sieve with a mesh between $20-30$ and ready 139 for use(Fazlzadeh et al. 2017).

\section{NZVI preparation using green synthesis technique}

142 Pomegranate peel extract was prepared by boiling for 60 minutes. The obtained extract was then

143 filtered by vacuum pump, filtered to form nanoparticles, $\mathrm{FeCl}_{2}$ solution with specified normality 144 is added to $250 \mathrm{cc}$ of distilled water and $\mathrm{FeCl}_{2}$ solution is added to the pomegranate peel extract. 145 The appearance of a darker colour indicates the formation of zero-capacity iron particles. The 146 nanoparticles were then placed in the oven at $70^{\circ} \mathrm{C}$ for $24 \mathrm{~h}$ to dry (Leili et al. 2018).

\section{LoadingnZVIon AC}

148 The composite was synthesized by adding $0.05 \mathrm{~g}$ of nZVI-NPs to $200 \mathrm{cc}$ of distilled water and 149 was stirred for 10 minto obtain a uniform solution. Following this, $5 \mathrm{~g}$ of AC was added to the 150 solution $\left(250 \mathrm{rpm}\right.$ for $2 \mathrm{~h}$ ). The composite putted in the oven (at $95^{\circ} \mathrm{C}$ temperature for $10 \mathrm{~h}$ ) 151 (Rashtbari et al. 2020b).

\section{Batchfurfuraladsorption studies.}

153 In the present study, Sulfuric acid and sodium hydroxide $0.1 \mathrm{M}$ were used to adjust the pH.The 154 furfural stock solution was prepared by diluting. The adsorption study was performed with a $\mathrm{pH}$ 155 change from (3-5-7-9-11) amount of adsorbent (0.5-1-2-3-5-6 g/L), furfural concentration (100$156 \quad 150-250-350 \mathrm{mgL}^{-1}$ ) and contact time (5 to $120 \mathrm{~min}$ ). The removal efficiency and the amount of 157 furfural adsorption in the adsorbent mass unit after the adsorption process were determined 158 through Eqs 1 and 2, respectively (Rashtbari et al. 2020a, Shokoohi et al. 2018)

$159 \% R=\frac{\left(C_{0}-C_{f}\right)}{C_{0}} 100(1)$ 
$160 q_{e}=\frac{\left(C_{0}-C_{e}\right) V}{M}(2)$

161 where, $C_{0}$ and $C_{e}$ are the initial furfuralconcentration and equilibrium liquid phase concentration 162 of furfural $(\mathrm{mg} / \mathrm{L})$ respectively, $C_{f}$ is the final furfuralconcentration, $M$ is the amount of adsorbent 163 and $V$ is the volume of the solution (L), AC-nZVI nanoparticles (g).

164

165 Evaluation of zero charge point $\left(\mathbf{p H}_{\mathrm{pzc}}\right)$

166 Fifty milliliters of $0.1 \mathrm{M} \mathrm{NaCl}$ solution was poured into $150 \mathrm{~mL}$ Erlenmeyer flakes with a $\mathrm{pH}$ 167 adjusted with sulfuric acid and sodium hydroxide in the range of 2-12. An amount of $0.04 \mathrm{~g}$ of 168 nanocomposite was added to the solutions (stirred for $48 \mathrm{~h}$ ). The final $\mathrm{pH}$ was measured and its curve was plotted against the initial $\mathrm{pH}$. The point on the curve that intersects the bisector was identified as the $\mathrm{pH}_{\mathrm{pzc}}$ nanocomposite (Ali et al. 2020, Rivera-Utrilla et al. 2010).

171

\section{Results and discussion}

\section{Composite characteristics analysis}

174 The FTIR analysis of activated carbon and AC-nZVI composite is shown in Fig. 1(a). The 175 adsorption peak $900-1300 \mathrm{~cm}^{-1}$ belongs to the phosphorus-containing functional groups, which 176 are the activation of phosphoric acid used during the preparation process (Ghaedi et al. 2013) and 177 the peaks used. The wavelengths generated between $400-1800 \mathrm{~cm}^{-1}$ are related to the vibrations 178 of Fe-O bonds. The presence of nZVI nanoparticles can be proved by the appearance of an 179 absorption band at $506 \mathrm{~cm}^{-1}$ (Bhatia et al. 2018). The 3000-2800 band with a peak of $2850 \mathrm{~cm}^{-1}$ 180 in the AC-nZVI composite is related to the presence of the C-H alkanes band (EPA 2006).The 181 peak observed for AC and AC-nZVI in the band $13432 \mathrm{~cm}^{-1}$ can be related to the O-H vibration 182 in the $\mathrm{H}_{2} \mathrm{O}$ molecule (Mohan \&Pittman 2006). Also, the peaks observed in bands 2925 and 2850 183 as indicated (EPA 2006) involvement of $\mathrm{C}-\mathrm{H}$ and $\mathrm{O}-\mathrm{H}$ (acidic group) of pomegranate peel 184 extract in the formation of particles(Leili et al. 2018).Absorption peaks appear at the absorption 185 wavelengths in 1030, 1456, 1634, 2932 and 3426 corresponding to the functional groups of 186 polyphenol compounds. Therefore, it can be claimed that the polyphenols in the extract play a 187 double role as reducing the metal ion and converting it to nanoparticles and as a stabilizing 
nanoparticle (Sun et al. 2014).Some peaks disappeared after nZVI coverage in AC and decreased irregularity in the AC-nZVI spectrum. Overall, nZVI coverage on AC has been successful.

190 The XRD result shows that the AC-nZVI-NPs owns a crystalline structure that improves the

191 process of adsorption through physical adsorption. The maximum peak of around $2 \theta=32$ (with

192 very high intensity) was also observed on the XRD image (Fig. 1(b)).Fig.2 shows the results of 193 the morphology of the adsorbent surface. According to Fig2 (a), the surface of activated carbon

194 has a favourable porosity. These cavities provide a good opportunity for nZVI nanoparticles to 195 be trapped inside. In Fig.2(b), nZVI nanoparticles can also be seen as white particles. These 196 nanoparticles are dispersed and evenly distributed on the activated carbon surface. Stabilization 197 of nanoparticles on activated carbon partially blocks surface porosity, probably because zero198 capacity iron nanoparticles cannot enter the internal cavities of activated carbon tissue and 199 therefore remain on the outer surface of activated carbon. The FE-SEM image of the stabilized 200 nanoparticles indicates that the porosity composite has a suitable specific surface area and the 201 zero-capacity iron nanoparticles are well stabilized on the activated carbon (Rashtbari et al. 202 2020b, Sun et al. 2014).

203 BET analysis was performed based on measuring the volume of nitrogen gas absorbed and 204 desorbed by the material surface at a constant temperature of liquid nitrogen (77 K) to calculate 205 the pore volume and surface area. This analysis was performed by BET device (Quanta chrome 206 Instruments, CHEMBET 3000). Fig. 3 shows the results of the BET analysis of AC-nZVI 207 nanocomposite. Table 1, it can be seen that the porosity of nanocomposite is more than activated 208 carbon. The area of specific surface area of activated carbon and nanocomposite is calculated as 209731.12 and $821.74 \mathrm{~m}^{2} \mathrm{~g}^{-1}$, respectively. This result shows that by adding nZVI nanoparticles to 210 the activated carbon, the adsorbent surface area increased. The maximum amount of adsorbent 211 pores was in the range of $3.08 \mathrm{~nm}$, which indicates the microscopic structure.

\section{The effect of $\mathbf{p H}$ on process efficiency}

$214 \mathrm{pH}$ is the most important parameter in the adsorption process. The effect of $\mathrm{pH}$ of 3, 5, 7, 9 and 21511 with a reaction time of 60 minutes at a concentration of $250 \mathrm{mg} / \mathrm{L}$. Results obtained by 216 studding the $\mathrm{pH}$ effect on the adsorption efficiency of furfural on Nano-composites are presented 217 in Figs. 4 (A,B). The presented data in Fig.4 (b) indicated that with increasing of the pH from 3 218 to 7 , the adsorption of furfural on Nano-composites surface has also increased. According to the 
219 experimental results, it was observed that the removal efficiency under neutral $\mathrm{pH}$ conditions is 220 slightly higher than the alkaline and acidic conditions. At this stage, $\mathrm{pH} 7$ was selected as the 221 optimal $\mathrm{pH}$. At $\mathrm{pH}<\mathrm{pH}_{\mathrm{pzc}}$, the AC-nZVI had a positive charge and in $\mathrm{pH}>\mathrm{pH}_{\mathrm{pzc}}$, it had a 222 negative charge. As a result, in solutions with a $\mathrm{pH}<6.76$, the nanocomposite had a positive 223 charge at its surface, while the furfural dye molecules were negatively charged. As the $\mathrm{pH}$ 224 decreases due to the increase of ${ }^{+} \mathrm{H}$ ions in the solution, the formation of electrostatic attraction 225 between the $+\mathrm{H}$ ion and the dye increases that ultimately increases the adsorption rate as well. 226 On the other hand, nanocomposite had a negative charge due to $\mathrm{pH}>6.76$, so the anionic dye 227 and the adsorbent repelled (Fazlzadeh et al. 2018, Sun et al. 2014) as reported earlier (Sahu et al. 228 2008). 


\section{Examining the effect of adsorbent dose}

231 The adsorbent dose determines the adsorbent capacity for a given initial concentration of 232 furfural, Fig. 5 shows the changes in the furfural adsorption process by the composite. In 233 experiments performed on $100 \mathrm{~mL}$ samples with a concentration of $250 \mathrm{mg} / \mathrm{L}$ of paint, the 234 contact time was 60 minutes, $\mathrm{pH}$ was 7 and doses of $0.5,1,2,3,4,5$ and $6 \mathrm{~g} / \mathrm{L}$ were performed. 235 It was found that the removal rate in furfural increases with increasing the amount of adsorption. 236 The furfural removal increased from $22.28 \%$ to $83.32 \%$ by increasing the dose from 0.5 to $6 \mathrm{~g} / \mathrm{L}$.

237 The $\mathrm{q}_{\max }$ decreased with increasing dose therefore the $\mathrm{q}_{\max }$ of furfuraldecreased from $111.42 \mathrm{mg} / \mathrm{g}$ 238 to $34.72 \mathrm{mg} / \mathrm{g}$; therefore, the optimal dose of $4 \mathrm{~g} / \mathrm{L}$ was selected. The results show that with 239 increasing the adsorbent dose, the furfural removal efficiency increases, which changes faster in 240 the adsorbent dose to $4 \mathrm{~g} / \mathrm{L}$. After $4 \mathrm{~g} / \mathrm{L}$, the removal efficiency has been a gentle and almost 241 constant process. Increased furfural uptake occurs to increase the adsorbent dose due to the 242 increase in the number of positive sites, the increase in the adsorbent surface and the presence of 243 a strong driving force. At low doses of adsorbent, fewer active sites are provided to the furfural 244 molecules, which leads to a decrease in removal efficiency (Mebrek \&Derriche 2010). These 245 findings were found to be consistent with a previous study for the furfural removal by active 246 carbon(Mouni et al. 2018).

\section{Effect of time andthe initial concentration}

249 Fig. 6 shows the effect of contact time on furfural uptake. Another influential factor in furfural 250 removal is contact time. In order to evaluate the optimal contact time for experiments in the range of 350-100 mg/L under optimal conditions of $\mathrm{pH}=7$ and the amount of adsorbent $4 \mathrm{~g} / \mathrm{L}$, was evaluated at times from 0 to 120 minutes. The stirrer speed was $250 \mathrm{rpm}$ and the experiments were performed at a temperature of $25^{\circ} \mathrm{C}$. As shown in Fig. 6, the adsorbent removal efficiency was performed at high speed in 60 minutes and then increased with a gentle slope to 120 minutes and reached almost equilibrium. Therefore, the optimal contact time for the adsorbent was chosen to be 60 minutes. The rate of pollutant diffusion into the pores decreases, followed by the rate of adsorption. On the other hand, initially, the surfaces available to absorb the contaminant on the adsorbent are completely free and as a result, the adsorbent is in contact with the contaminant with all surfaces and over time the available surfaces become less and thus the adsorption rate decreases (Fazlzadeh et al. 2018). Similar results were also reported in 
261 previous studies (Fazlzadeh et al. 2018, Sahu et al. 2008, Zhang et al. 2019).Fig. 6 shows the 262 effect of the initial concentration of furfural on the removal efficiency of AC-nZVI from the 263 furfural aqueous solution. It was observed that the removal efficiency was declined with 264 increasing furfural concentration at the equilibrium time of $60 \mathrm{~min}$. As the initial concentration 265 of furfural increased from 100 to $250 \mathrm{mg} / \mathrm{L}$, the furfural removal efficiency by AC-nZVI 266 increased from $85.9 \%$ to $90.93 \%$, respectively. This may be owed to the finite number of active 267 sites on the adsorbent that becomes saturated at higher concentrations of furfural. In other words, 268 at low concentrations, the availability of the active AC-nZVI sites to the furfural molecules is more than when high concentrations of furfuralare involved (Fang \&Yang 2021).

\section{Isotherm studies}

272 Isotherm plots for furfural adsorption are shown in Fig. 7 (pH 7, AC-nZVI dose of 4 g/L and $25 \pm$ $2732^{\circ} \mathrm{C}$ ). Table 2 displays the isotherm parameters at ideal conditions.Providing the $\mathrm{r}^{2}$ values 274 obtained for the tested theoretical models (Table 2), it can be observed that the tow isotherm 275 models (Langmuir, Freundlich) conform firmly to the experimental result. As the paradigm, 276 Freundlich describes a method of chemical adsorption. An adsorption intensity (n) of 1.74 within 2771 to $10(1<\mathrm{n}<10)$ for furfuraladsorption indicates a desirable adsorption process on AC-nZVI 278 (Shu et al. 2020, Zhang et al. 2019). The isotherm parameters and $R^{2}$ values for Langmuir, 279 Freundlich models are calculated from slopes andintercepts by plotting 1/Ceversus 1/qe(Fig. 7a), $280 \log \mathrm{C}_{\mathrm{e}}$ ersuslog $\mathrm{q}_{\mathrm{e}}$ (Fig. 7b), respectively.The isotherm plots for furfuraladsorption by AC-nZVI 281 -NPs at the optimum conditions of $\mathrm{pH} 7$, a dose of $4 \mathrm{~g} / \mathrm{L}$ and temperature of $25 \pm 2^{\circ} \mathrm{C}$ as shown in 282 Fig. 8.

\section{Kinetic studies}

285 Kinetic experiments are conducted to track the mechanism that governs an adsorption process 286 (Shu et al. 2020). To test the kinetic data, kinetic adsorption models (pseudo-first-order, pseudo287 second-order, and intraparticle diffusion models) were used. The equations of linear kinetic 288 models with kinetic parameter definition are given in Table 3.pseudo-first-order are estimated 289 from the intercepts and slopes of plots between $\log \left(\mathrm{q}_{\mathrm{e}}-\mathrm{q}_{\mathrm{t}}\right)$ versus $\mathrm{t}$ (Fig. 9a), $\mathrm{q}_{\mathrm{e}}$ and $\mathrm{k}_{2}$ for 290 pseudo-second-order are estimated from slopsand intercepts of plots between t/qtversus $t$ (Fig. 291 9b). The findings obtained on linear adsorption kinetics are summarized in Table 3.The kinetic 
292 parameters were derived from the kinetic models' plots at maximum pH 7 conditions and $4 \mathrm{~g} / \mathrm{L}$ 293 doses of nanoparticles. The regression coefficients $\left(\mathrm{r}^{2}\right)$ verified the correlation between the

294 predicted kinetic model values and the experimental results. The pseudo-second-order kinetic 295 model is found to fit characterize the kinetic experimental data with its values of $r^{2}$ closer to 296 unity. This means that adsorption of furfural to AC-nZVI is a chemical adsorption form 297 (Fazlzadeh et al. 2018).

\section{Adsorbent reclamation}

299 The adsorbent recovery process is considered to get their economic value and solve operational 300 problems. AC-nZVI was recovered using $0.1 \mathrm{M} \mathrm{NaOH}$ solution. As seen in Fig. 10, the 301 performance was $93.44 \%$, which decreased to $81.74 \%$ (five recovery cycles), suggesting that the 302 restored adsorbent already has a high potential to adsorb the AC-nZVI and can be used regularly. 303 The $\mathrm{NaOH}$ and the furfural $\mathrm{i}$ in the active AC-nZVI sites interact, and the furfuralis isolated from 304 the active sites.Therefore, nanocomposite has a high potential for wastewater treatment in the 305 pharmaceutical industry. Because it can be reused after five consecutive periods by recovering 306 the adsorbent and by its ability to maintain the removal efficiency. It is also cost-effective and 307 therefore very necessary for industrial applications to prevent secondary pollution in the 308 treatment of wastewater (De Gisi et al. 2016).

\section{Comparison of AC-nZVInanocomposite for furfural}

311 The deposition of on the composite AC-nZVI was compared The performance of 312 furfuralremoval obtained using AC-nZVI shows that furfuralremoval from its aqueous solution 313 can be implemented. The deposition of furfural (for an initial concentration of $250 \mathrm{mg} / \mathrm{L}, \mathrm{pH}=7$, 314 dose $=4 \mathrm{~g} / \mathrm{L}$, Tim $=60 \mathrm{~min}$, stirring speed $=250 \mathrm{rpm}$ and $\mathrm{Tem}=25 \pm 2^{\circ} \mathrm{C}$ ) was compared in the 315 presence of AC-nZVI (Fig11) usingAC as an adsorbent under same condition. Afurfural 316 adsorbtion of $81.87 \%$ and $62.06 \%$ were obtained using adsorption AC-nZVI and AC, 317 respectively. Using AC-nZVI, afurfural adsorbtion of $81.87 \%$ was achieved within 60 min. This 318 improvement was associated with the combination AC and nZVI nanoparticles which increased 319 surface adsorption (Fazlzadeh et al. 2018). Presently, from various methods, adsorbtion are 320 considered auspicious treatments to remove various recalcitrant furfural. Based on Table 4, 321 numerous researchers have examined furfural removal in aqueous environments via several 322 adsorbent. At the other end, desorption process is a favourable method for the removal of 
furfural. In addition to suitable removal efficiency, other benefits include its moderate costs and non-toxicity. However, the majority of the results in Table 4 are better than that of the present study. In addition, a new composite that can be used for adsorbtion processes was obtained but more studies are required in order to make this process a feasible option.

\section{Conclusions}

329 The adsorption of furfural onto AC-nZVI nanoparticles was examined in this report. The 330 findings of this analysis show that furfuralcan be extracted in a very short time by the process of 331 adsorbing on AC-nZVI nanoparticles. The effects of various operating parameters such as $\mathrm{pH}$ (3 332 11), dosage $(0.5-6 \mathrm{~g} / \mathrm{L})$, contact time $(5-120 \mathrm{~min})$, temperature $(298 \mathrm{~K})$, and initial 333 concentration of fluoride $(100-350 \mathrm{mg} / \mathrm{L})$ on fluoride adsorption were studied.Furthermore, the 334 removal efficiency of $81.46 \%$ was observed at the best conditions (furfural: $250 \mathrm{mg} / \mathrm{L}, \mathrm{pH}$ of 7 , 335 and AC-nZVI dosage of $4 \mathrm{~g} / \mathrm{L}$ and contact time of $60 \mathrm{~min}$ ). The process of furfural adsorption on 336 AC-nZVI was found to depend on the Freundlich adsorption isotherm models. Monolayer 337 adsorption capacity of AC-nZVI was $222.22 \mathrm{mg} / \mathrm{g}$. The kinetic data fitted best into the pseudo338 second-order model considering the values of the regression coefficients $\left(\mathrm{r}^{2}\right)$.AC-nZVI with a 339 very high capability is nevertheless convenient economically to remove various contaminants 340 from water. It could be concluded that the synthesized AC-nZVIcan be used as an effective 341 adsorbent for furfural ions removal from aqueous solutions.

\section{Appendix}

343 The crude data extracted from literature included.

344 Author contributionYousef Poureshgh and Yousef Rashtbari participated in the 345 conceptualization and design of the research and supervised the work. Shirin Afshin and Asghar 346 Hamzezadeh are responsible for experimental analysis and interpretation of data. Ayoob 347 Rastegar contributed to literature search and quality assessment, Shahin Ahmadi, Farooq Sher 348 and Soumya Ghosh wrote the first draft of manuscript. All authors have read and approved the 349 final paper as submitted.

350 Ethical Approval: The authors of this article have covered all the ethical points, including non351 plagiarism, duplicate publishing, data distortion, and data creation in this article. This project has been 352 registered in Ardabil University of Medical Sciences with the code of ethics 353 ofIR.ARUMS.REC.1398.018

354 Consent to Participate: Not applicable

355 Consent to Publish: Not applicable 
357 Availability of data and materialsAll the data and material pertinent tothis manuscript are

358 included and have been reviewed by all authors.

\section{Declarations}

360 Competing interest The authors declare no competing interests.

\section{Acknowledgements}

362 This research received funding from project no. IR.ARUMS.REC.1398.018 (Ardabil University

363 of Medical Sciences).The authors sincerely appreciate the monetary and instrumental supports

364 from Ardabil University of Medical Sciences.

Ali I, Afshin S, Poureshgh Y, Azari A, Rashtbari Y, Feizizadeh A, Hamzezadeh A, Fazlzadeh M (2020): Green preparation of activated carbon from pomegranate peel coated with zero-valent iron nanoparticles (nZVI) and isotherm and kinetic studies of amoxicillin removal in water. Environ. Sci. Pollut. Res 27, 36732-36743

Anbia M, Mohammadi N (2009): A nanoporous adsorbent for removal of furfural from aqueous solutions. Desalination 249, 150-153

Bhatia D, Datta D, Joshi A, Gupta S, Gote Y (2018): Adsorption study for the separation of isonicotinic acid from aqueous solution using activated carbon/ $/ \mathrm{Fe}_{3} \mathrm{O}_{4}$ composites. Journal of Chemical \& Engineering Data 63, 436-445

Borghei SM, Hosseini SN (2008): Comparison of furfural degradation by different photooxidation methods. Chem Eng J 139, 482-488

De Gisi S, Lofrano G, Grassi M, Notarnicola M (2016): Characteristics and adsorption capacities of lowcost sorbents for wastewater treatment: A review. Sustain Mater Techno 9, 10-40

Doddapaneni TRKC, Jain R, Praveenkumar R, Rintala J, Romar H, Konttinen J (2018): Adsorption of furfural from torrefaction condensate using torrefied biomass. Chem. Eng. J 334, 558-568

Elaheh JM, Saeed M, Momasood MS, Ali JS (2011 ): Survey of the environmental impact of the petrochemical industry of mahshahr economic special zone using the analytic hierarchy process method. Environmental Sciences 8, 145 - 156

EPA ( 2006): Pesticide Fact Sheet (Office of Prevention, Pesticide and Toxic Substance). Contract No: 7505P Office of Prevention, Pesticide and Toxic Substance

Fahmi MR, Abidin CZA, Rahmat NR (2011): Characteristic of colour and COD removal of azo dye by advanced oxidation process and biological treatment, International Conference on Biotechnology and Environment Management. ACSIT Press, Singapoore, pp. 13-18

Fang K, Yang R (2021): A comparison on the efficiency of raw activated carbon, oxidized, and sulfurized adsorbents for furfural adsorption. Alexandria Eng. J 60, 1241-1248

Faramarzpour M, Vossoughi M, Borghei M (2009): Photocatalytic degradation of furfural by titania nanoparticles in a floating-bed photoreactor. Chem Eng J 146, 79-85

Fazlzadeh M, Khosravi R, Zarei A (2017): Green synthesis of zinc oxide nanoparticles using Peganum harmala seed extract, and loaded on Peganum harmala seed powdered activated carbon as new adsorbent for removal of Cr(VI) from aqueous solution. Ecol Eng 103, 180-190

Fazlzadeh M, Ansarizadeh M, Leili M (2018): Data of furfural adsorption on nano zero valent iron (NZVI) synthesized from Nettle extract. Data in brief 16, 341-345 
Ghaedi M, Ghayedi M, Kokhdan SN, Sahraei R, Daneshfar A (2013): Palladium, silver, and zinc oxide nanoparticles loaded on activated carbon as adsorbent for removal of bromophenol red from aqueous solution. J Ind Eng Chem 19, 1209-1217

Hoydonckx HE, Van Rhijn W, M., Van Rhijn W, De Vos D, Jacobs P (2000): Furfural and Derivatives, Enclyclopedia of Industrial Chemistry

Iram M, Guo C, Guan YP, Ishfaq A, Liu HZ (2010): Adsorption and magnetic removal of neutral red dye from aqueous solution using $\mathrm{Fe}_{3} \mathrm{O}_{4}$ hollow nanospheres. J. Hazard. Mater181, 1039-1050

Leili M, Fazlzadeh M, Bhatnagar A (2018): Green synthesis of nano-zero-valent iron from Nettle and Thyme leaf extracts and their application for the removal of cephalexin antibiotic from aqueous solutions. Environ Technol 39, 1158-1172

Li C, Zhong S, Duan L, Song Y ( 2011): Evaluation of petrochemical wastewater treatment technologies in Liaoning province of China. Procedia Environ. Sci 10, 2798-2802

Mao LY, Zhang L, Gao NB, Li AM (2012): $\mathrm{FeCl}_{3}$ and acetic acid co-catalyzed hydrolysis of corncob for improving furfural production and lignin removal from residue. Bioresource Technol 123, 324331

Mebrek OR, Derriche Z (2010): Removal of Furfural from aqueous solutions by adsorption using Organobentonite: Isotherm and kinetic studies. Adsorpt Sci Technol 28, 533-545

Mohan D, Pittman CU (2006): Activated carbons and low cost adsorbents for remediation of tri- and hexavalent chromium from water. J. Hazard. Mater137, 762-811

Mouni L, Belkhiri L, Bollinger J-C, Bouzaza A, Assadi A, Tirri A, Dahmoune F, Madani K, Remini H (2018): Removal of Methylene Blue from aqueous solutions by adsorption on Kaolin: Kinetic and equilibrium studies. Appl. Clay Sci 153, 38-45

OSHA. Washington D (1992): Occupational Safety and Health Guideline. In: Labor USDo (Hrsg.)

Ramezani F, Kazemi B, Jebali A (2013): Biosynthesis of silver nanoparticles by Leishmania sp. New Cellular and Molecular Biotechnology Journal 3, 107-111

Rashtbari Y, Afshin S, Hamzezadeh A, Abazari M, Poureshgh Y, Fazlzadehdavh M (2020a): Application of powdered activated carbon coated with zinc oxide nanoparticles prepared using a green synthesis in removal of reactive blue 19 and reactive black-5: adsorption isotherm and kinetic models. Desalin. Water Trea 179, 354-367

Rashtbari Y, Hazrati S, Azari A, Afshin S, Fazlzadeh M, Vosoughi M (2020b): A novel, eco-friendly and green synthesis of PPAC-ZnO and PPAC-nZVI nanocomposite using pomegranate peel: Cephalexin adsorption experiments, mechanisms, isotherms and kinetics. Adv Powder Technol $31,1612-1623$

Rivera-Utrilla J, Sanchez-Polo M, Prados-Joya G, Ferro-Garcia MA, Bautista-Toledo I (2010): Removal of tinidazole from waters by using ozone and activated carbon in dynamic regime. J. Hazard. Mater174, 880-886

Sahu AK, Srivastava VC, Mall ID, Lataye DH (2008): Adsorption of furfural from aqueous solution onto activated carbon: Kinetic, equilibrium and thermodynamic study. Sep. Sci. Technol 43, 12391259

Shen S, Ren JF, Chen J, Lu XH, Deng CH, Jiang XG (2011): Development of magnetic multiwalled carbon nanotubes combined with near-infrared radiation-assisted desorption for the determination of tissue distribution of doxorubicin liposome injects in rats. J Chromatogr A 1218, 4619-4626

Shokoohi R, Samadi MT, Amani M, Poureshgh Y (2018): Optimizing laccase-mediated amoxicillin removal by the use of box-behnken design in an aqueous solution. Desalin. Water Treat 119, 5363

Shu HY (2006): Degradation of dyehouse effluent containing CI Direct Blue 199 by processes of ozonation, $\mathrm{UV} / \mathrm{H}_{2} \mathrm{O}_{2}$ and in sequence of ozonation with $\mathrm{UV} / \mathrm{H}_{2} \mathrm{O}_{2}$. J. Hazard. Mater133, 92-98

Shu YR, Ji B, Cui BH, Shi YT, Wang J, Hu M, Luo SY, Guo DB (2020): Almond shell-derived, Biocharsupported, nano-zero-valent Iron composite for aqueous hexavalent Chromium removal: Performance and mechanisms. Nanomaterials-Basel 10 
Singh S, Srivastava VC, Mall ID (2009): Fixed-bed study for adsorptive removal of furfural by activated carbon. Colloid Surface A 332, 50-56

Sun Q, Cai X, Li JW, Zheng M, Chen ZL, Yu CP (2014): Green synthesis of silver nanoparticles using tea leaf extract and evaluation of their stability and antibacterial activity. Colloid Surface A 444, 226-231

USEPA ER (1998): Handbook of Advanced Photochemical Oxidation Processes. Office of Research and Development, Cincinnati, Ohio 45268,

Yang WD, Li PL, Bo DC, Chang HY (2012): The optimization of formic acid hydrolysis of xylose in furfural production. Carbohyd Res 357, 53-61

Zeitsch KJ (2000): The Chemistry and Technology of Furfural and its Many By-Products. Sugar, 13. Elsevier

Zhang W, Zhu YL, Niu S, Li YW (2011): A study of furfural decarbonylation on K-doped $\mathrm{Pd} / \mathrm{Al}_{2} \mathrm{O}_{3}$ catalysts. J Mol Catal a-Chem 335, 71-81

Zhang XR, Yan L, Liu JF, Zhang ZY, Tan CH (2019): Removal of different kinds of heavy metals by novel PPG-nZVI Beads and their application in simulated stormwater infiltration facility. Appl Sci-Basel 9 
Table 2. Equilibrium parameters for Langmuir and Freundlich.

\begin{tabular}{|c|c|c|c|c|c|c|}
\hline \multicolumn{4}{|c|}{ Langmuir } & \multicolumn{3}{|c|}{ Freundlich } \\
\hline Equation $\frac{C_{e}}{q_{e}}=\frac{C_{e}}{q_{m}}+\frac{1}{q_{m} K_{L}}$ & & & & $q_{e}=I$ & & \\
\hline \multirow{2}{*}{ furfural } & $\mathrm{K}_{\mathrm{L}}(\mathrm{L} / \mathrm{mg})$ & $\mathrm{R}^{2}$ & $\mathrm{R}_{\mathrm{L}}$ & $\mathrm{K}_{\mathrm{f}}[(\mathrm{mg} / \mathrm{g})(\mathrm{mg} / \mathrm{L}) 1 / \mathrm{n}]$ & $\mathrm{n}$ & $\mathrm{R}^{2}$ \\
\hline & 0.002 & 0.9707 & 0.571 & 3.10 & 1.74 & 0.985 \\
\hline
\end{tabular}

480

481

Table 3. Kinetics parameters for pseudo first and pseudo second.

Pseudo first order Pseudo second order

\begin{tabular}{|c|c|c|c|c|c|c|c|}
\hline \multirow[b]{2}{*}{$\begin{array}{c}\mathbf{C}_{\mathbf{0}} \\
\mathrm{mg} / \mathrm{L}\end{array}$} & \multicolumn{4}{|c|}{$\log \left(q_{e}-q_{t}\right)=\log q_{e}-\frac{k_{1} t}{2.303}$} & \multicolumn{3}{|c|}{$t / q_{t}=1 / k_{2 p} q_{e}^{2}+t / q_{e}$} \\
\hline & $\begin{array}{c}\mathbf{q} \mathbf{e}, \mathbf{e p x} \\
\left(\mathrm{mg} \mathrm{g}^{-1}\right)\end{array}$ & $\begin{array}{c}\text { Qe1, cal } \\
\left(\mathrm{mg} \mathrm{g}^{-1}\right)\end{array}$ & $\begin{array}{c}\mathbf{k}_{\mathbf{1}} \\
\left(\min ^{-1}\right)\end{array}$ & $\mathbf{R}^{2}$ & $\begin{array}{c}\text { qe2, cal } \\
\left(\mathrm{mg} \mathrm{g}^{-1}\right)\end{array}$ & $\begin{array}{c}\mathbf{K}_{\mathbf{2}} \\
\left(\mathrm{gmg}^{-1} \mathrm{~min}^{-1}\right)\end{array}$ & $\mathbf{R}^{2}$ \\
\hline 100 & 24.25 & 20.62 & 0.0304 & 0.8589 & 24.51 & 0.0116 & 0.9984 \\
\hline 150 & 34.5 & 20.93 & 0.0295 & 0.9437 & 36.63 & 0.0029 & 0.9848 \\
\hline 250 & 58.75 & 44.86 & 0.0189 & 0.8526 & 60.98 & 0.0009 & 0.9506 \\
\hline 350 & 69.34 & 52.47 & 0.0122 & 0.7555 & 70.92 & 0.0004 & 0.8497 \\
\hline
\end{tabular}

482

483 
Table 4. Comparison of the Adsorption of Furfural onto Various Adsorbents

\begin{tabular}{|c|c|c|c|c|}
\hline Adsorbent material & $\begin{array}{c}\text { Maximum } \\
\text { removal (\%) }\end{array}$ & $\begin{array}{l}\text { Maximum } \\
\text { qmax }_{\operatorname{mg} / \mathrm{g})}\end{array}$ & Conditions & Reference \\
\hline Activated Carbon & 60 & 0.053 & $\begin{array}{l}\mathrm{pH}=5.9 \\
\text { Adsorbent dosage }=10 \mathrm{~g} / \mathrm{L} \\
\text { Initial concentration }=50 \\
\mathrm{mg} / \mathrm{L} \\
\text { Time }=60 \mathrm{~min} \\
\text { Temperature }=303 \mathrm{~K}\end{array}$ & (Sahu et al. 2008) \\
\hline torrefied biomass & 60 & 80 & $\begin{array}{l}\mathrm{pH}=2 \\
\text { Adsorbent dosage }=250 \mathrm{~g} / \mathrm{L} \\
\text { Initial concentration }=50 \\
\mathrm{mg} / \mathrm{L} \\
\text { Time }=30 \mathrm{~min}\end{array}$ & $\begin{array}{l}\text { (Doddapaneni et al. } \\
\text { 2018) }\end{array}$ \\
\hline MCM-48 & - & 196.1 & $\begin{array}{l}\mathrm{pH}=6 \\
\text { Adsorbent dosage }=0.1 \mathrm{~g} / \mathrm{L} \\
\text { Initial concentration }=1000 \\
\mathrm{mg} / \mathrm{L} \\
\text { Time }=1 \mathrm{~h} \\
\text { Temperature }=298 \mathrm{~K}\end{array}$ & $\begin{array}{c}\text { (Anbia \&Mohammadi } \\
\text { 2009) }\end{array}$ \\
\hline AC-nZVI & 81.3 & 222.22 & $\begin{array}{l}\mathrm{pH}=7 \\
\text { Adsorbent dosage }=4 \mathrm{~g} / \mathrm{L} \\
\text { Initial concentration }=250 \\
\mathrm{mg} / \mathrm{L} \\
\text { Time }=60 \mathrm{~min} \\
\text { Temperature }=25 \pm 2^{\circ} \mathrm{C}\end{array}$ & This study \\
\hline $\begin{array}{c}\text { synthesize zero valent } \\
\text { iron nanoparticles } \\
(\mathrm{NZVI})\end{array}$ & 87 & 454.4 & $\begin{array}{l}\mathrm{pH}=2 \\
\text { Adsorbent dosage }=0.5 \mathrm{~g} / \mathrm{L} \\
\text { Initial concentration }=100 \\
\mathrm{mg} / \mathrm{L} \\
\text { Time }=60 \mathrm{~min} \\
\text { Temperature }=298 \mathrm{~K} \\
\text { Speed }=200 \mathrm{rpm}\end{array}$ & (Fazlzadeh et al. 2018) \\
\hline Organobentonite & - & 536.3 & $\begin{array}{l}\mathrm{pH}=7 \\
\text { Adsorbent dose }=2 \mathrm{~g} / \mathrm{L} \\
\text { Contact time }=6 \mathrm{~h} \\
\text { Temperature }=30^{\circ} \mathrm{C} \\
\text { Initial fluoride concentration } \\
=100 \mathrm{mg} / \mathrm{L}\end{array}$ & $\begin{array}{c}\text { (Mebrek \&Derriche } \\
\text { 2010) }\end{array}$ \\
\hline
\end{tabular}

485 

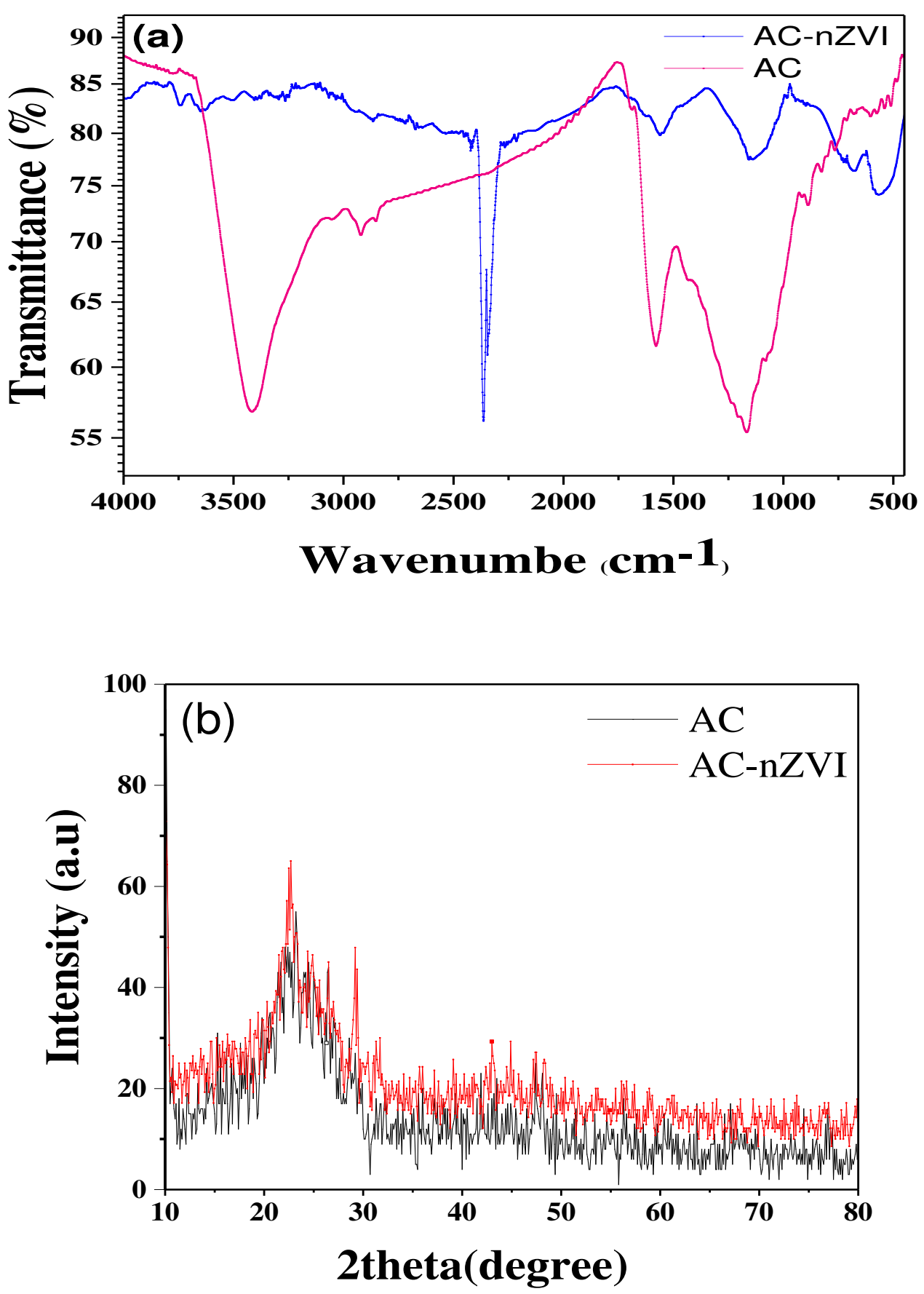

489

Fig. 1FTIR spectra (a) XRD patterns (b) of the AC and AC- nZVI- NPs.

491 


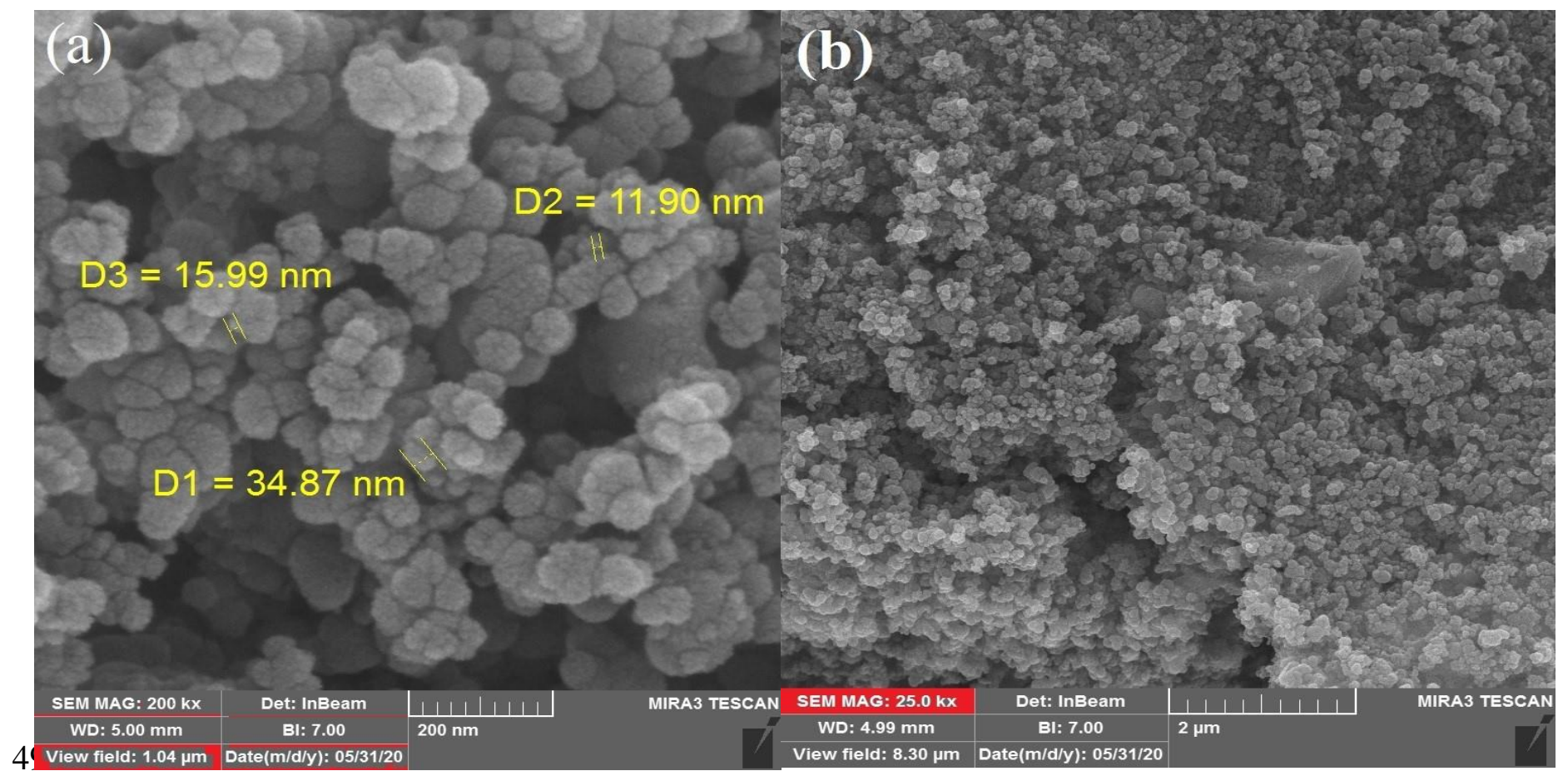

\section{View field: $1.04 \mu \mathrm{m}$ Date(m/d/y): 05/31/20}

View field: $8.30 \mu \mathrm{m}$ Date(m/d/y): 05/31/20

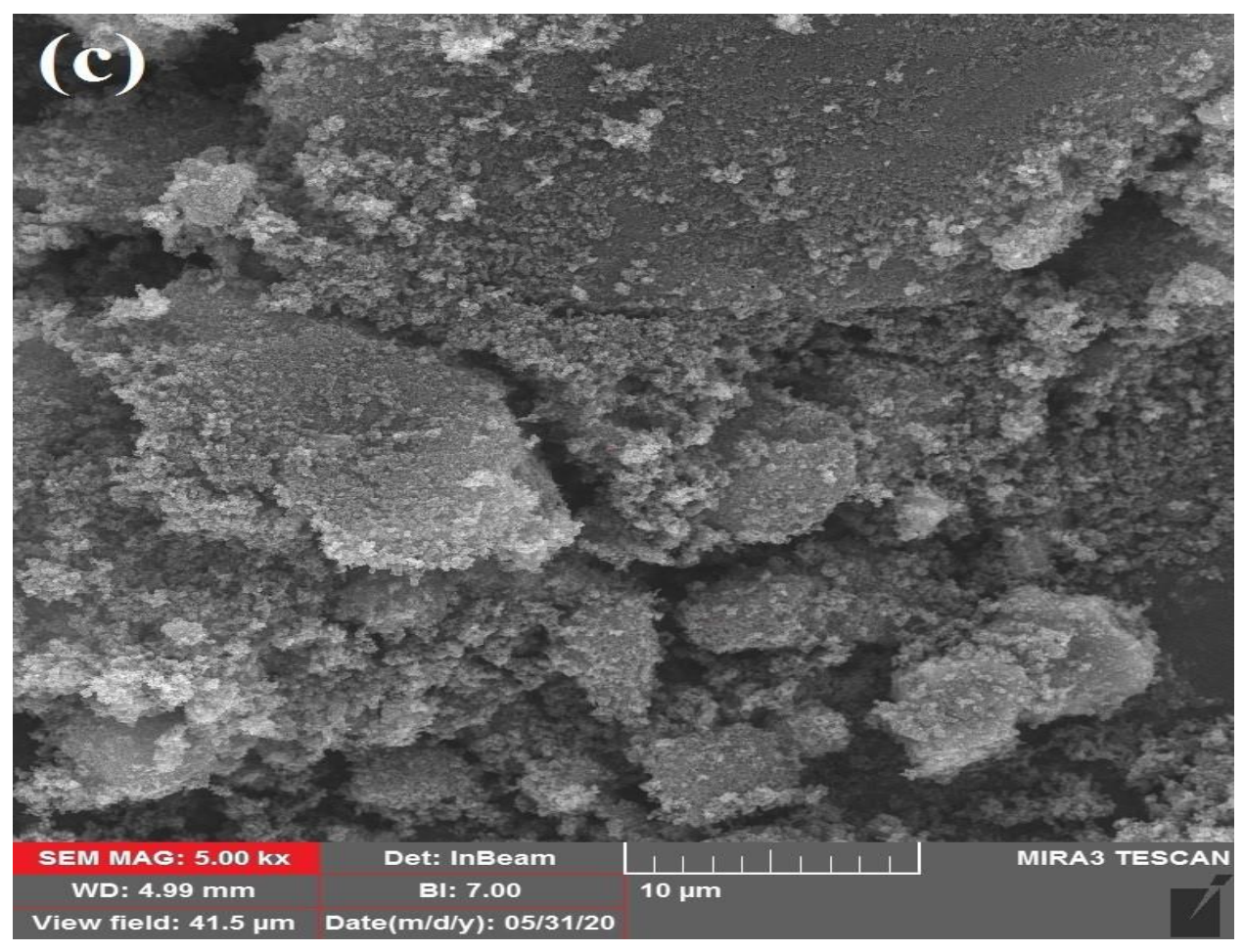

Fig.2 FE-SEM images of AC (a) and AC-nZVI -NPs (b, c). 


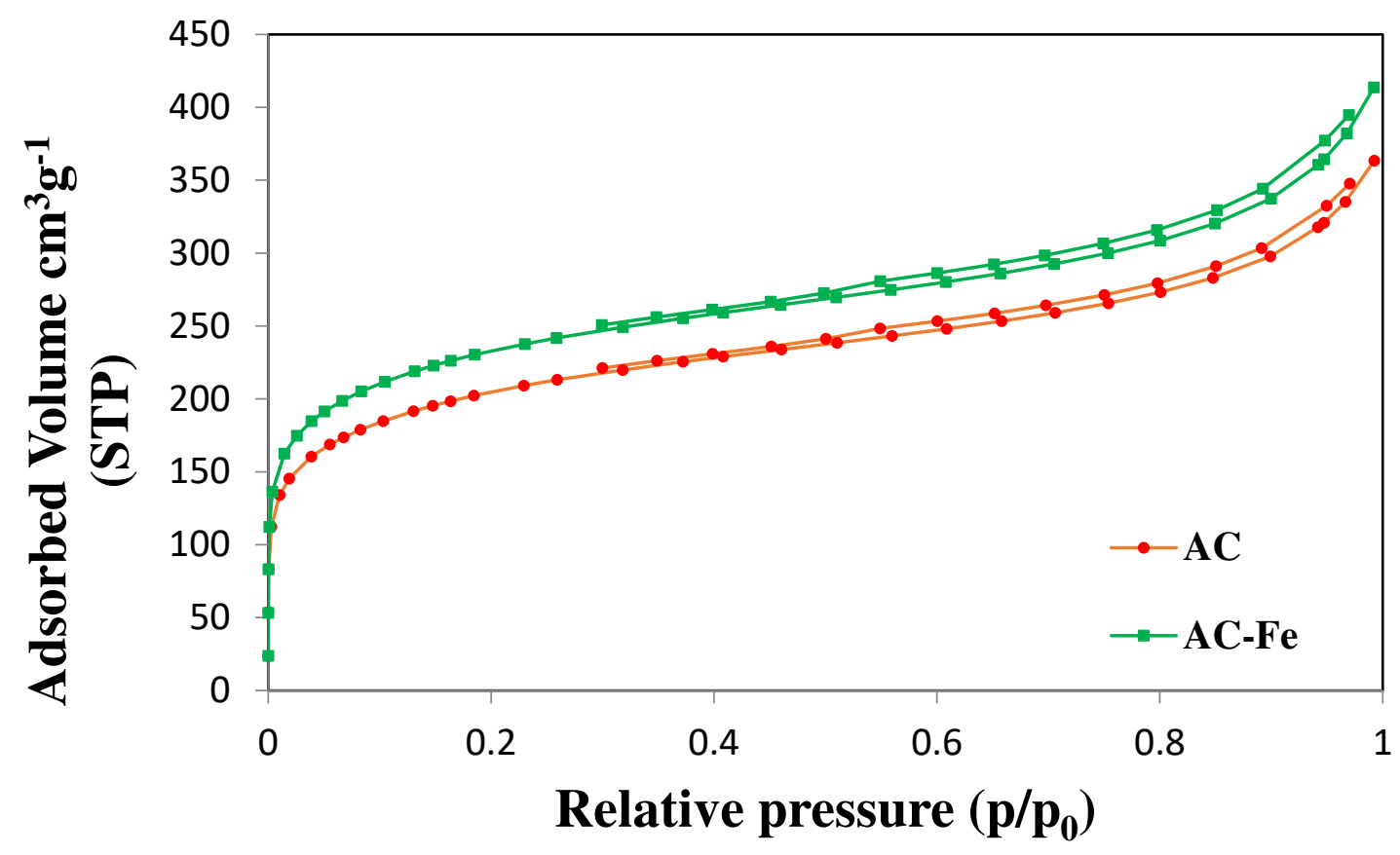

498

Fig. 3BET of AC and AC-n nZVI-NPs.

499 


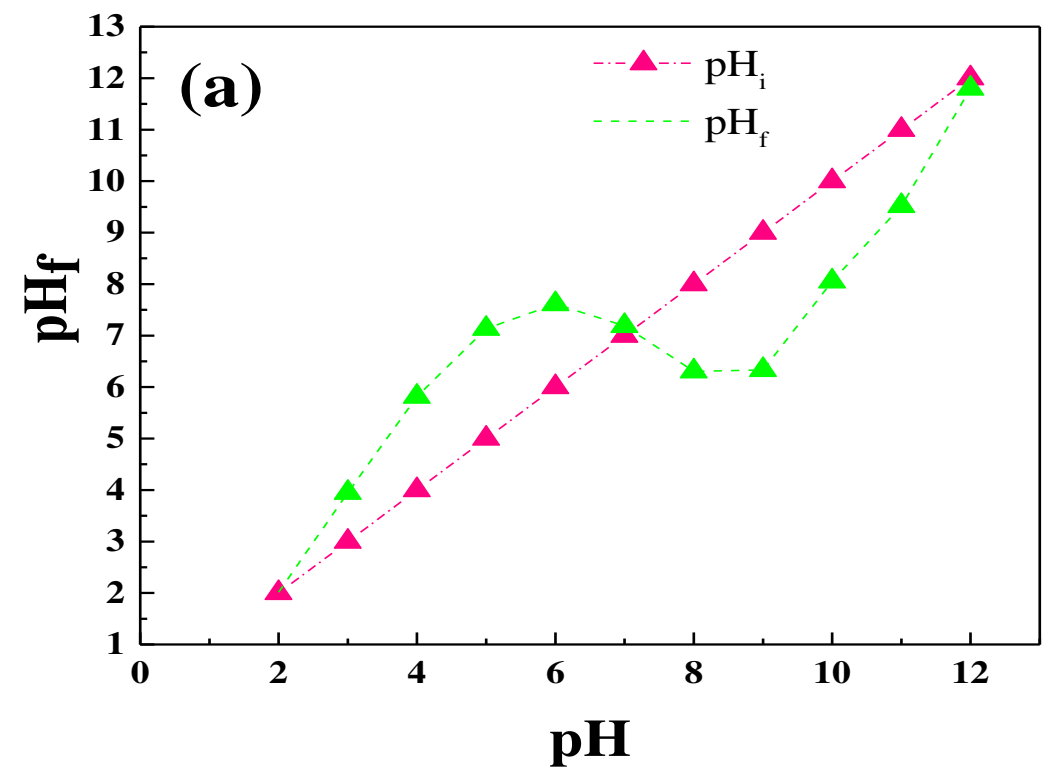

500

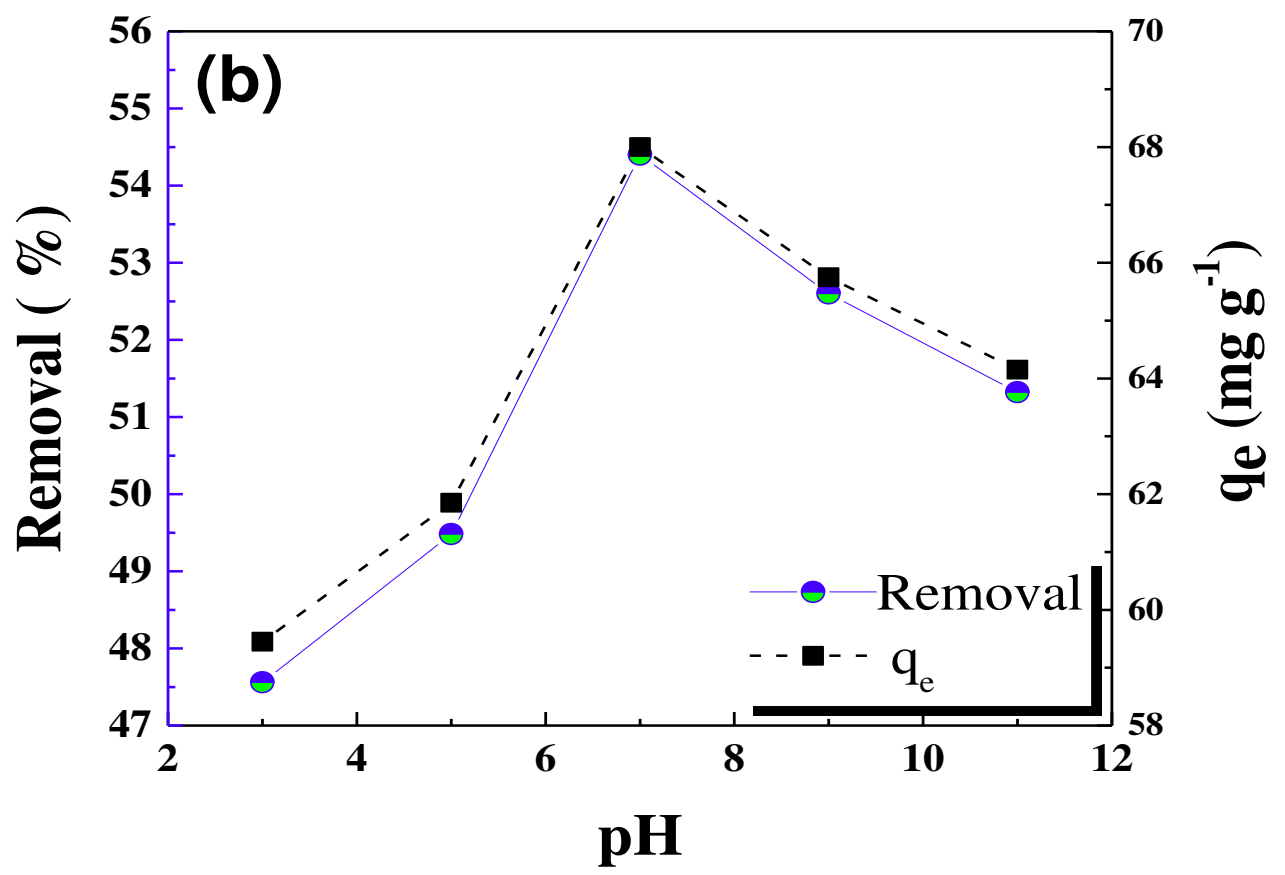

502 Fig.4Effect $\mathrm{pH}$ improves on the efficiency of removal of furfural, $\mathrm{pHpzc}$ (a) and $\mathrm{pH}(\mathrm{b})\left(\mathrm{C}_{0}=200 \mathrm{mg} / \mathrm{L}\right.$, 503 Tim $=60 \mathrm{~min}$, stirring speed $=250 \mathrm{rpm}$, Temp $=25 \pm 2^{0} \mathrm{C}$ ). 


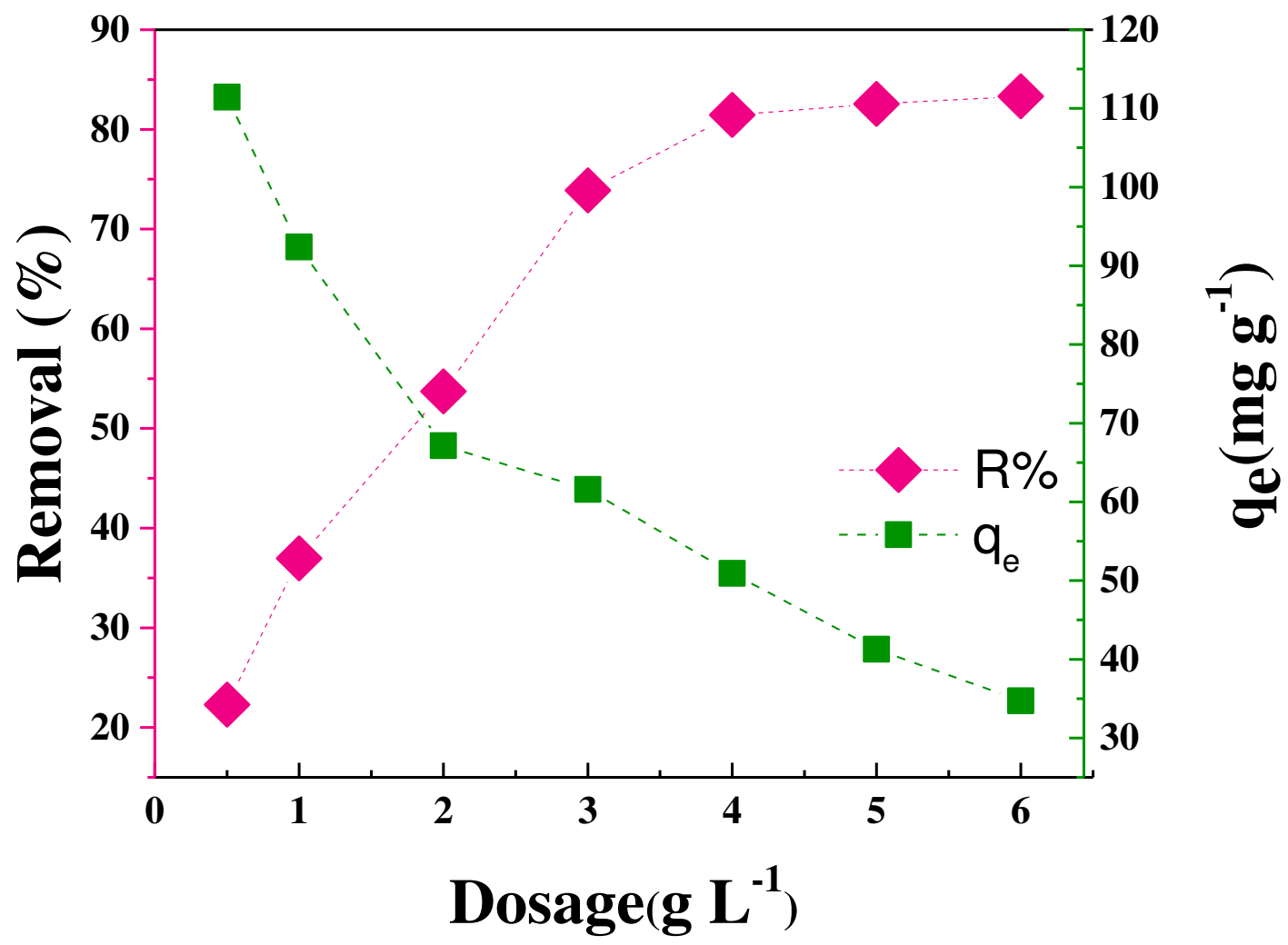

Fig. 5The effect of the AC-nZVI dosage varies on the removal efficiency of furfural $\left(\mathrm{C}_{0}=200 \mathrm{mg} / \mathrm{L}\right.$, 507 Tim $=60 \mathrm{~min}$, stirring speed $=250 \mathrm{rpm}$, Temp $=25 \pm 2^{\circ} \mathrm{C}$ and $\mathrm{pH}=7$ ). 


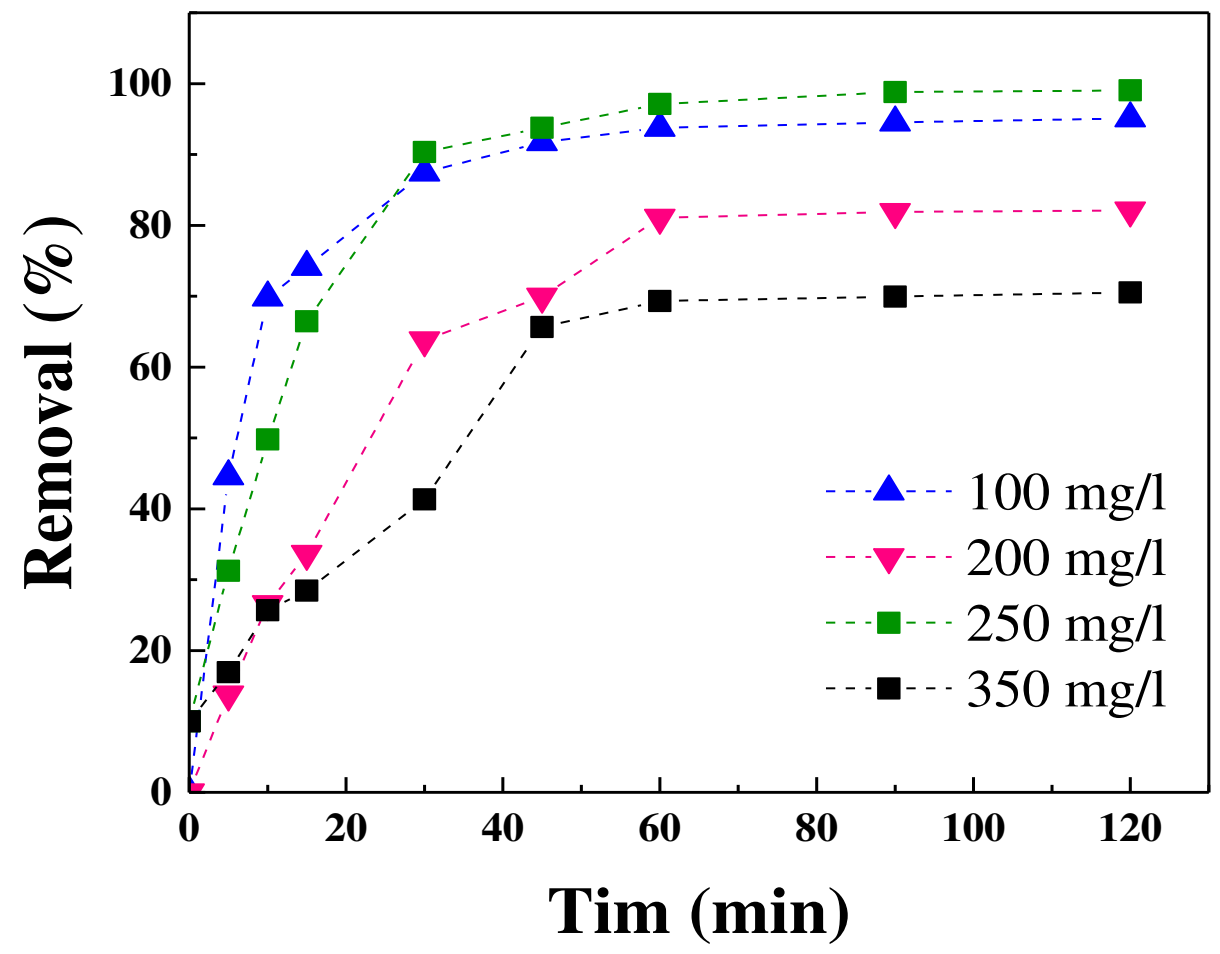

509

$510 \quad$ Fig. 6Effect of contact time and initial furfural Concentration for the adsorption of furfural onto AC511 nZVI-NPs $\left(\right.$ dose $=4 \mathrm{~g} / \mathrm{L}$, stirring speed $=250 \mathrm{rpm}$, Temp $=25 \pm 2^{\circ} \mathrm{C}$ and $\left.\mathrm{pH}=7\right)$. 


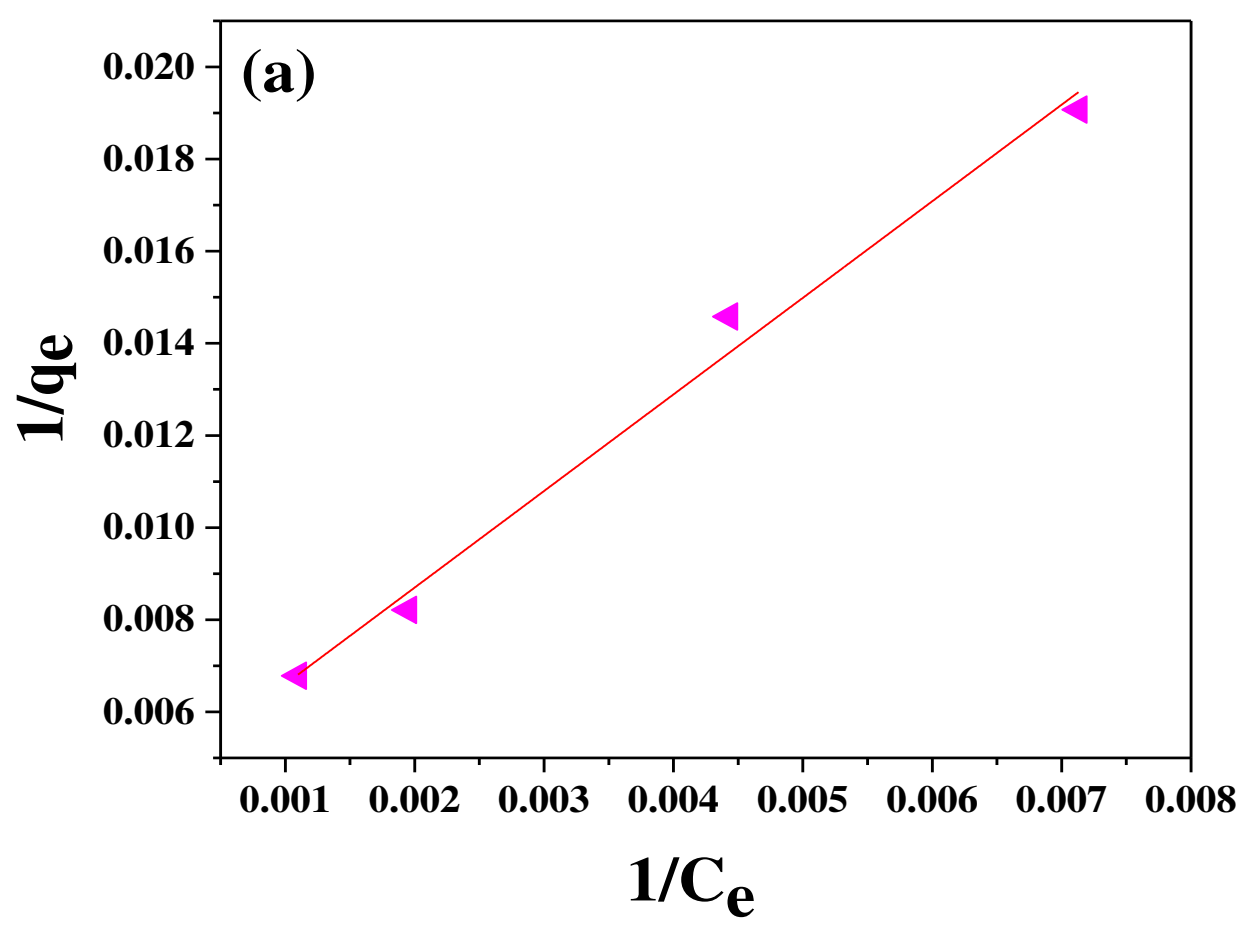

513

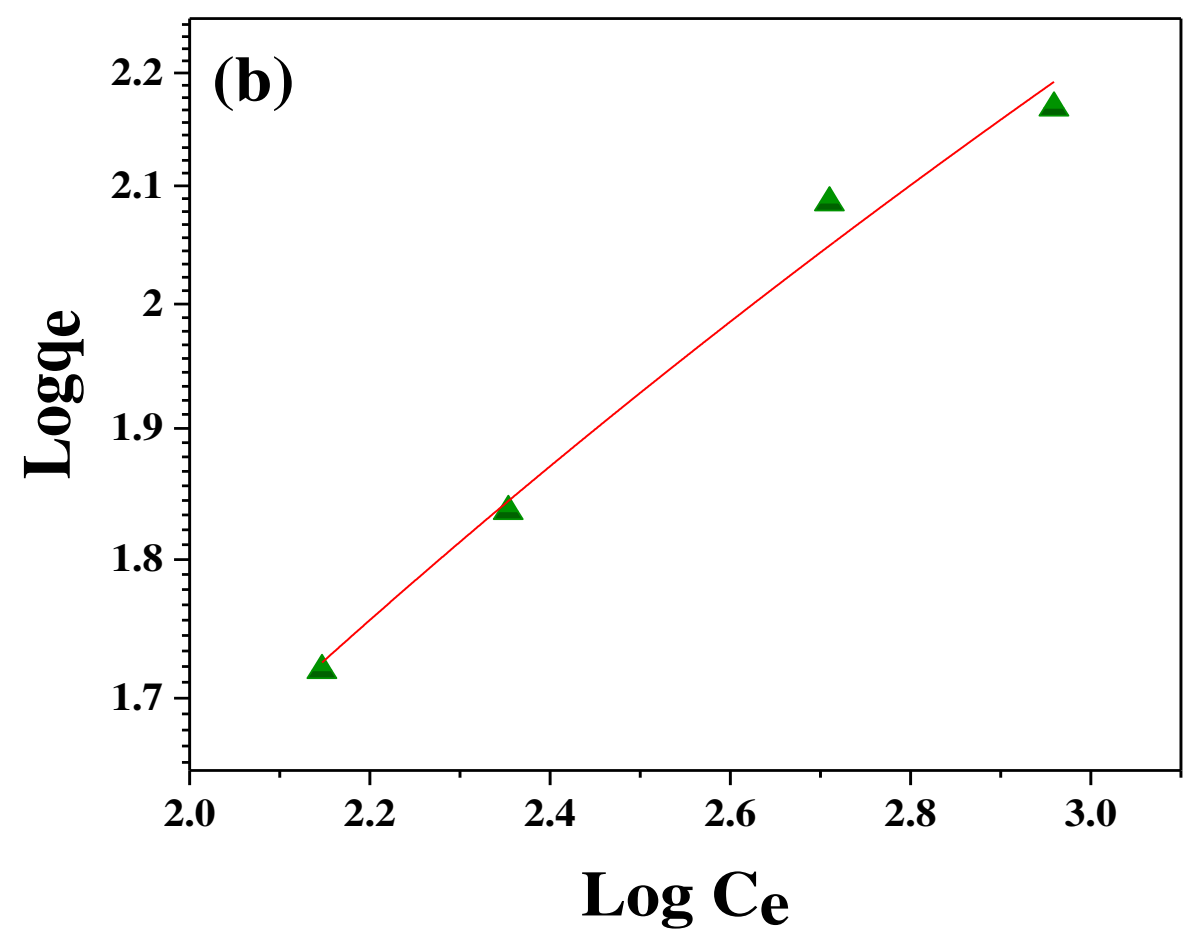

Fig.7Langmuir (a) andFreundlich (b) models for adsorption of furfural by AC-nZVI-NPs. 


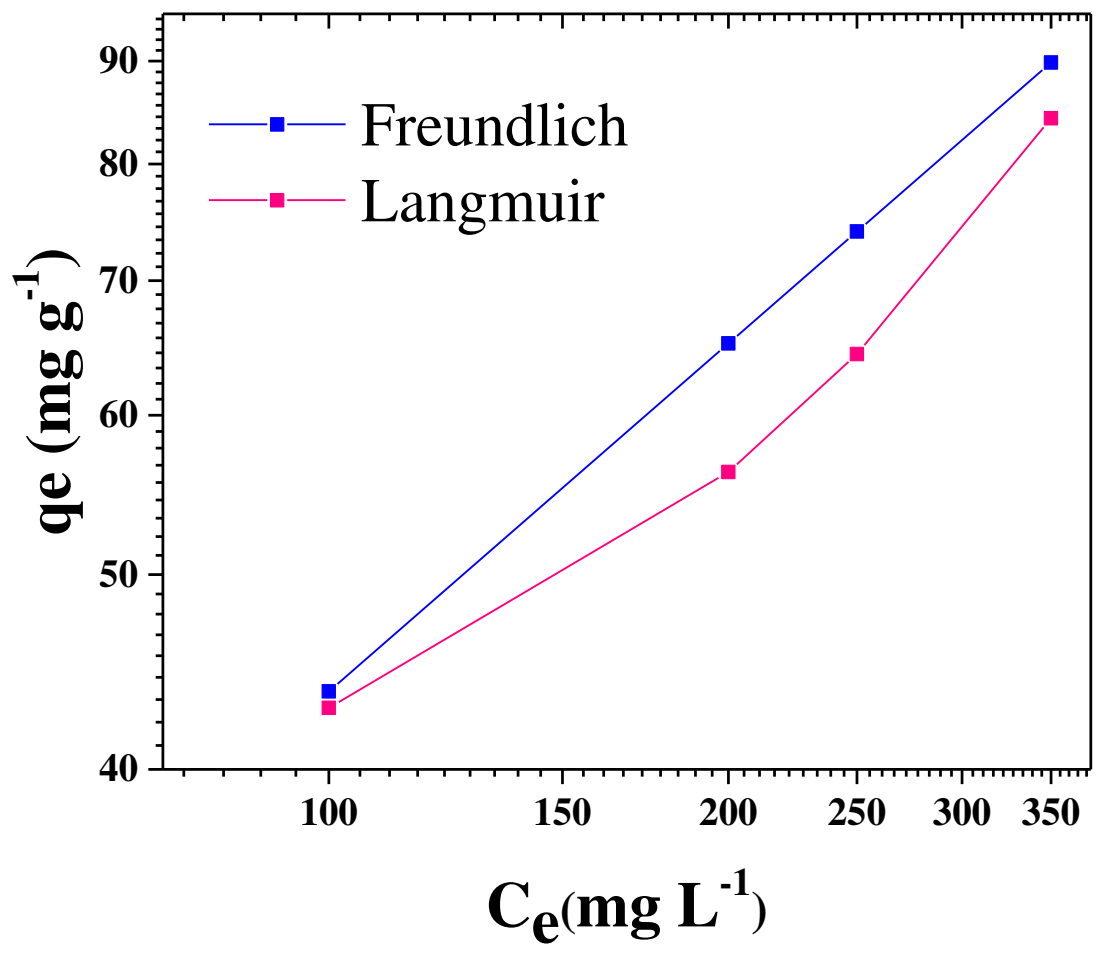

Fig. 8 Isotherm plots for furfuraladsorption by AC-nZVI-NPs ( $\mathrm{pH}=7$, dose $=4 \mathrm{~g} / \mathrm{L}, \mathrm{C}_{0}=250$ 519 $\mathrm{mg} / \mathrm{L}$, Tim $=60 \mathrm{~min}$ stirring speed $=250 \mathrm{rpm}$ and Temp $=25 \pm 2^{\circ} \mathrm{C}$ ). 

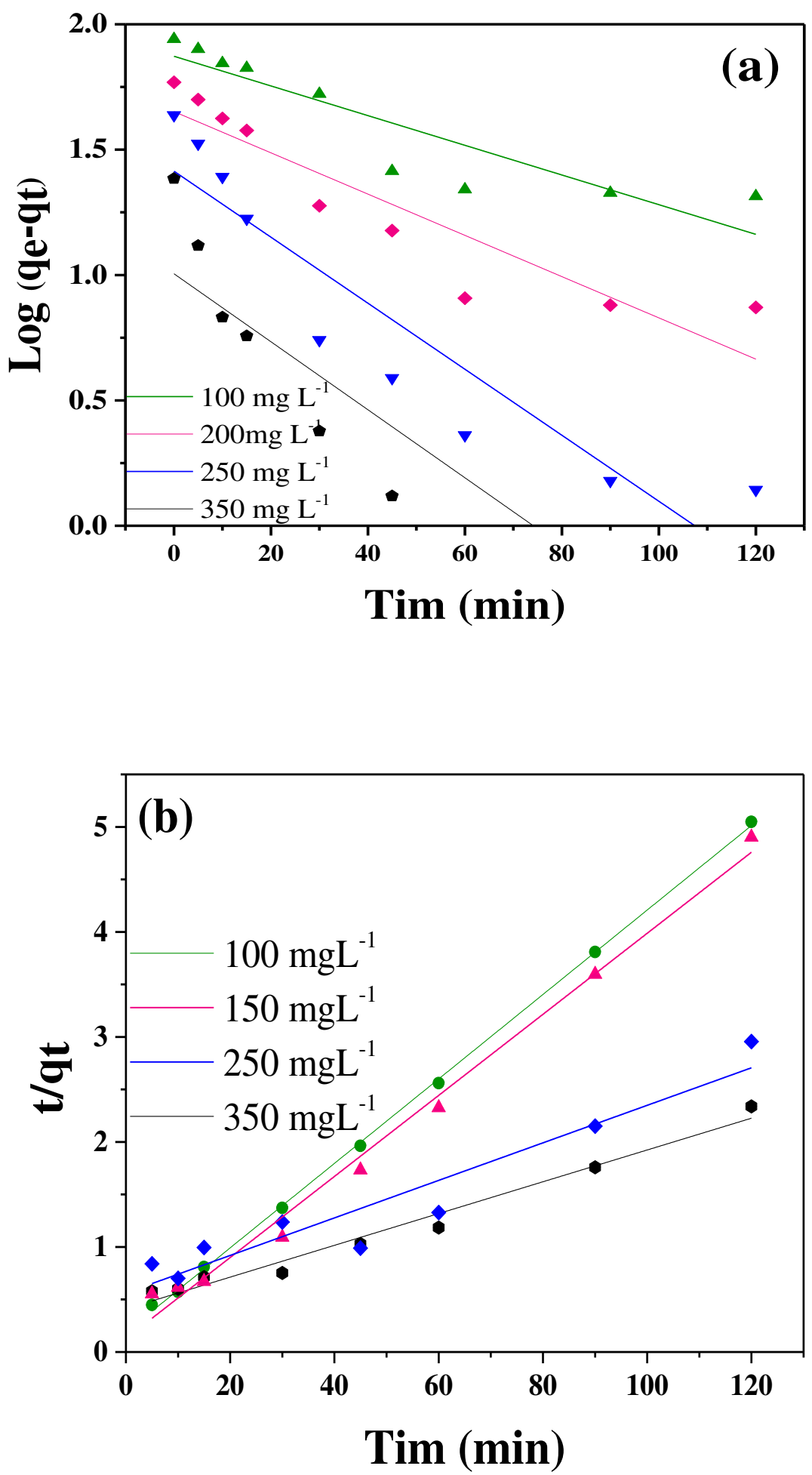

Fig. 9Pseudo first order (A) and second-order (B) kinetics models for the adsorption of furfuralby ACnZVI-NPs. 


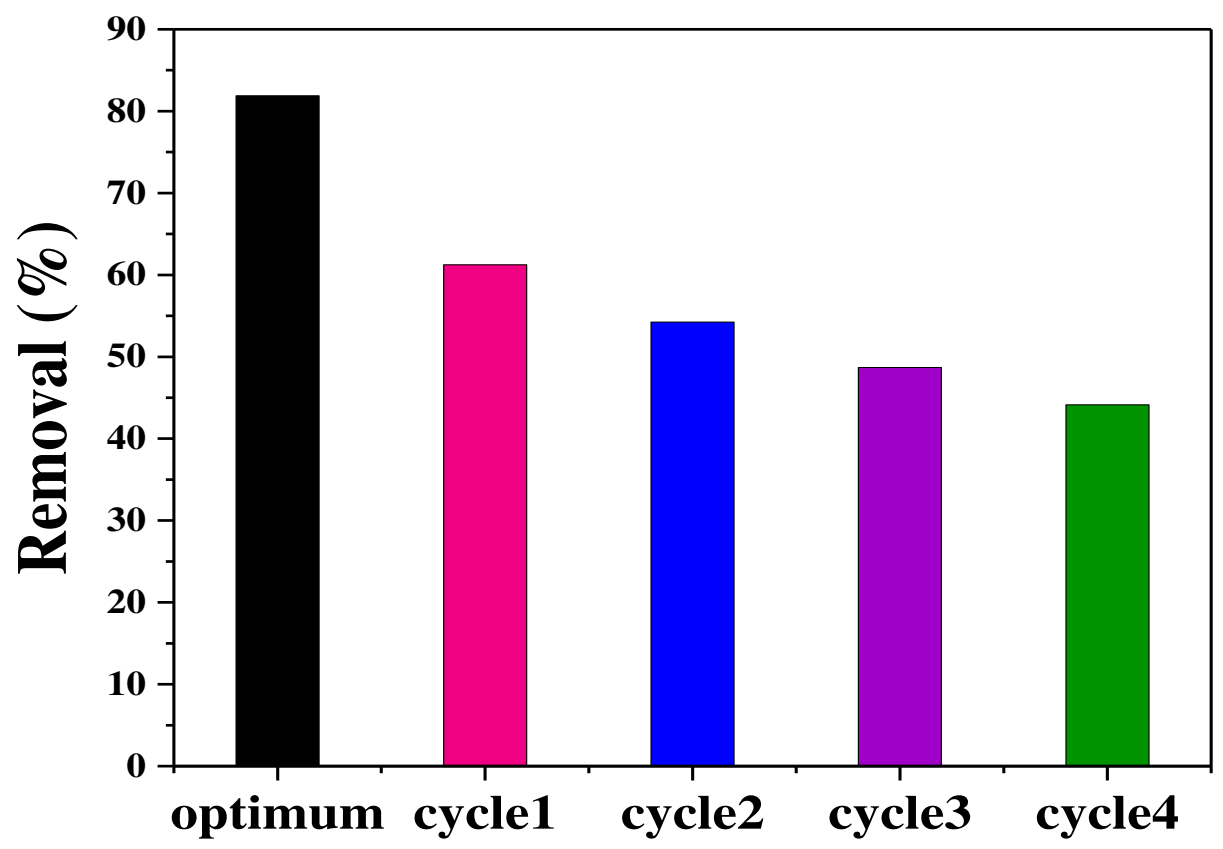

524

525

Fig. 10The AC-nZVI-NPs recovery in four stages.

526 


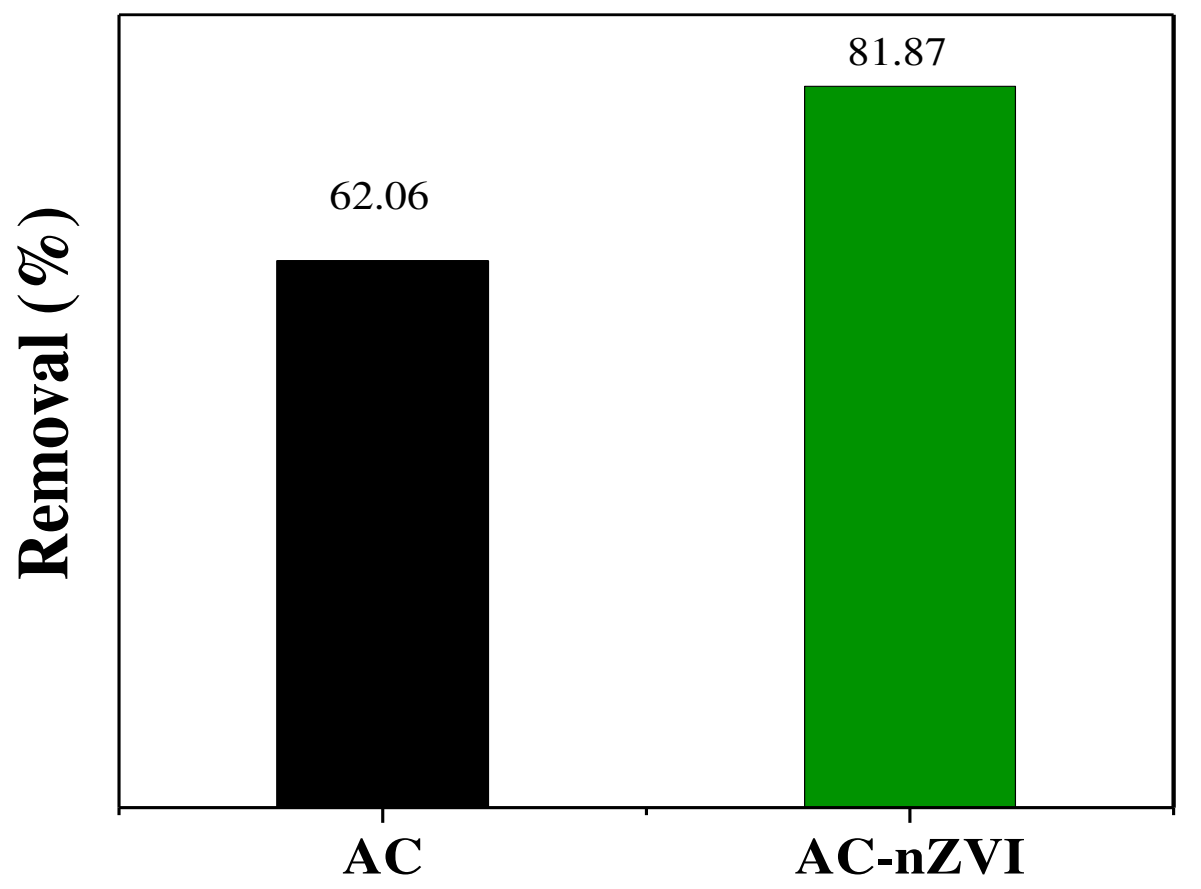

Fig. 11Comparison of different processes on the adsorption of furfural( $\mathrm{pH}=7$, dose $=4 \mathrm{~g} / \mathrm{L}, \mathrm{C}_{0}=250$ 530 $\mathrm{mg} / \mathrm{L}$, Tim $=60 \mathrm{~min}$, stirring speed $=250 \mathrm{rpm}$ and Tem $=25 \pm 2^{\circ} \mathrm{C}$ ). 
Figures
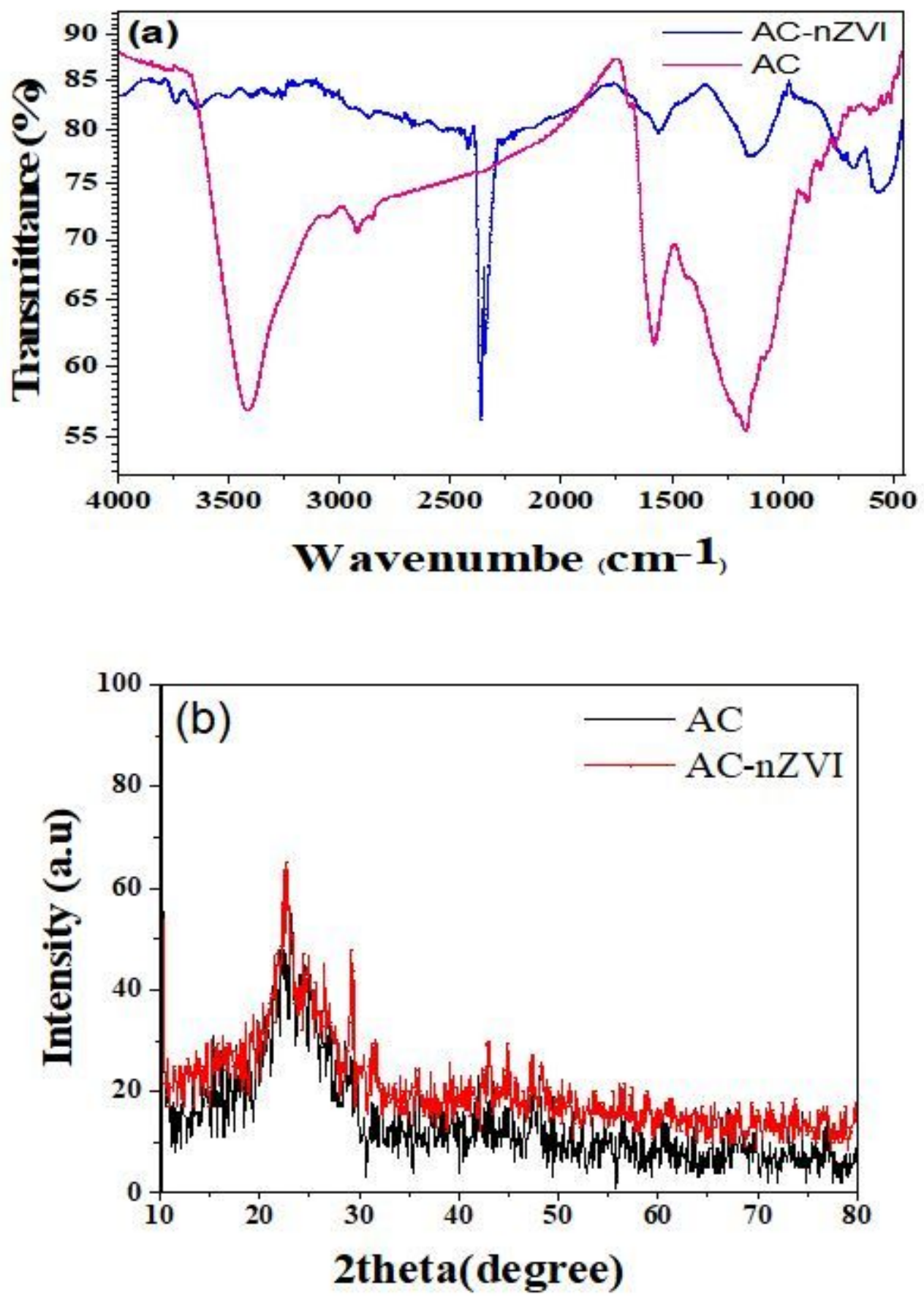

Figure 1

FTIR spectra (a) XRD patterns (b) of the AC and AC- nZVI- NPs. 

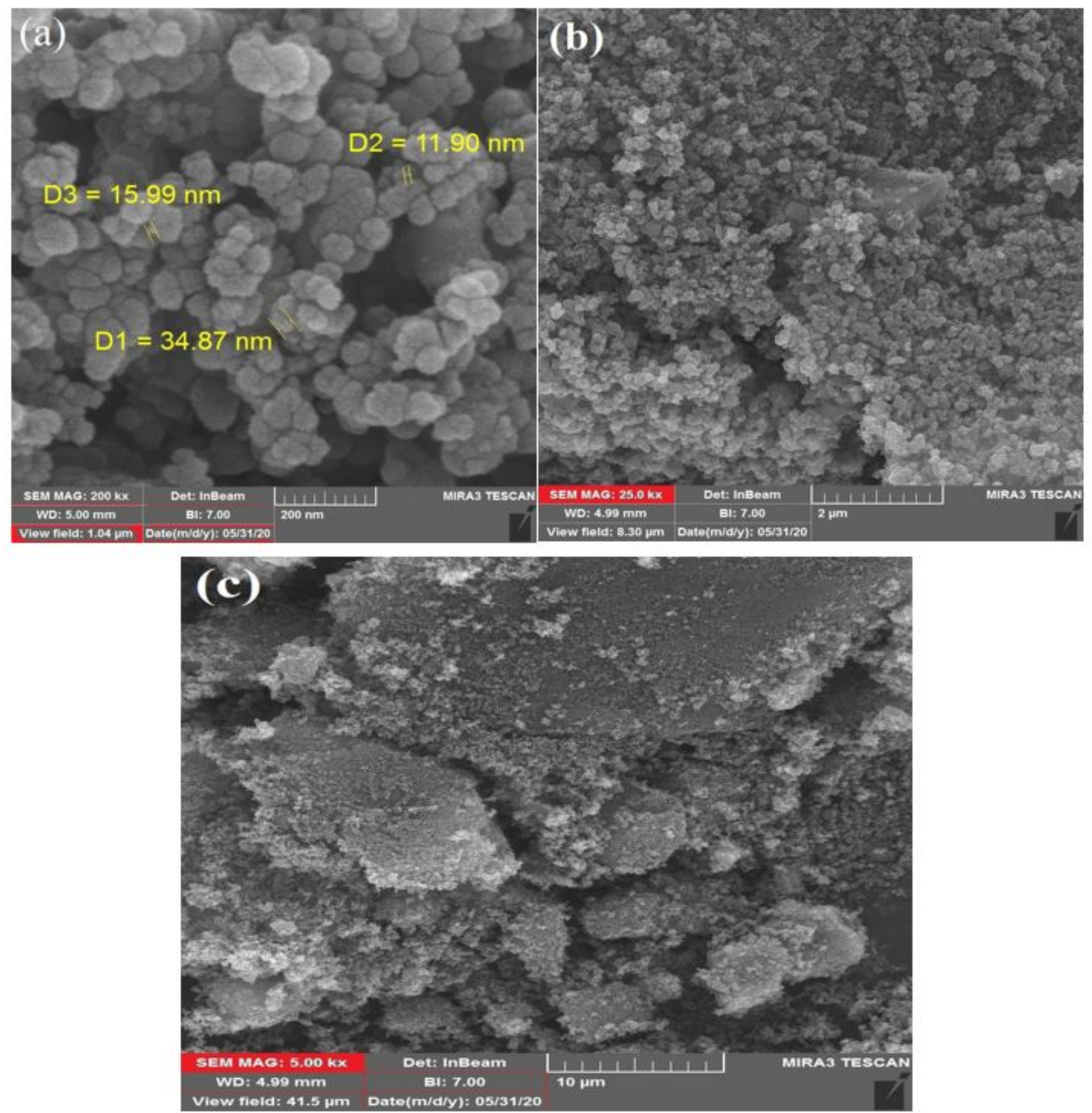

\section{Figure 2}

FE-SEM images of AC (a) and AC-nZVI-NPs (b, c). 


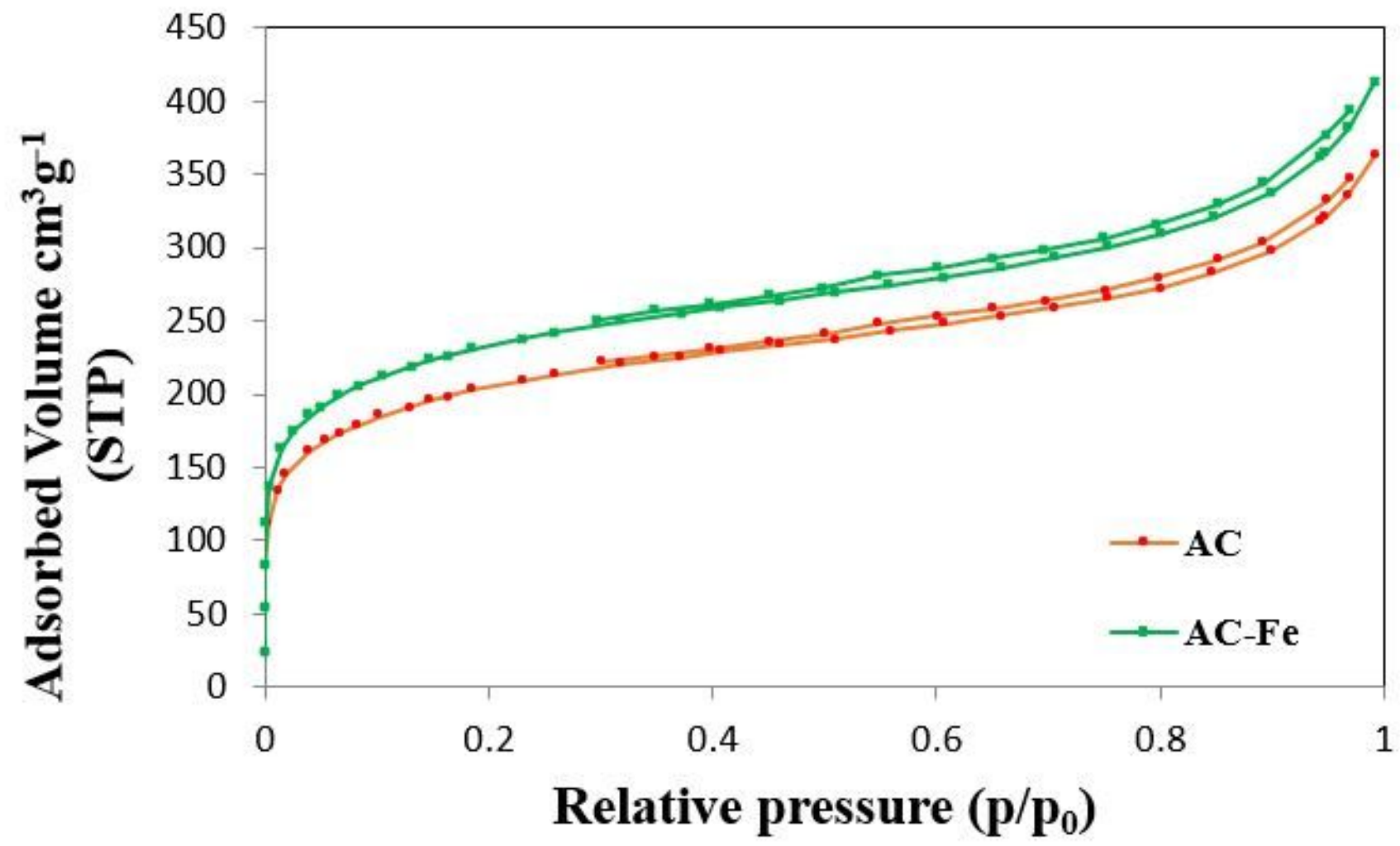

Figure 3

BET of AC and AC-n nZVI-NPs. 

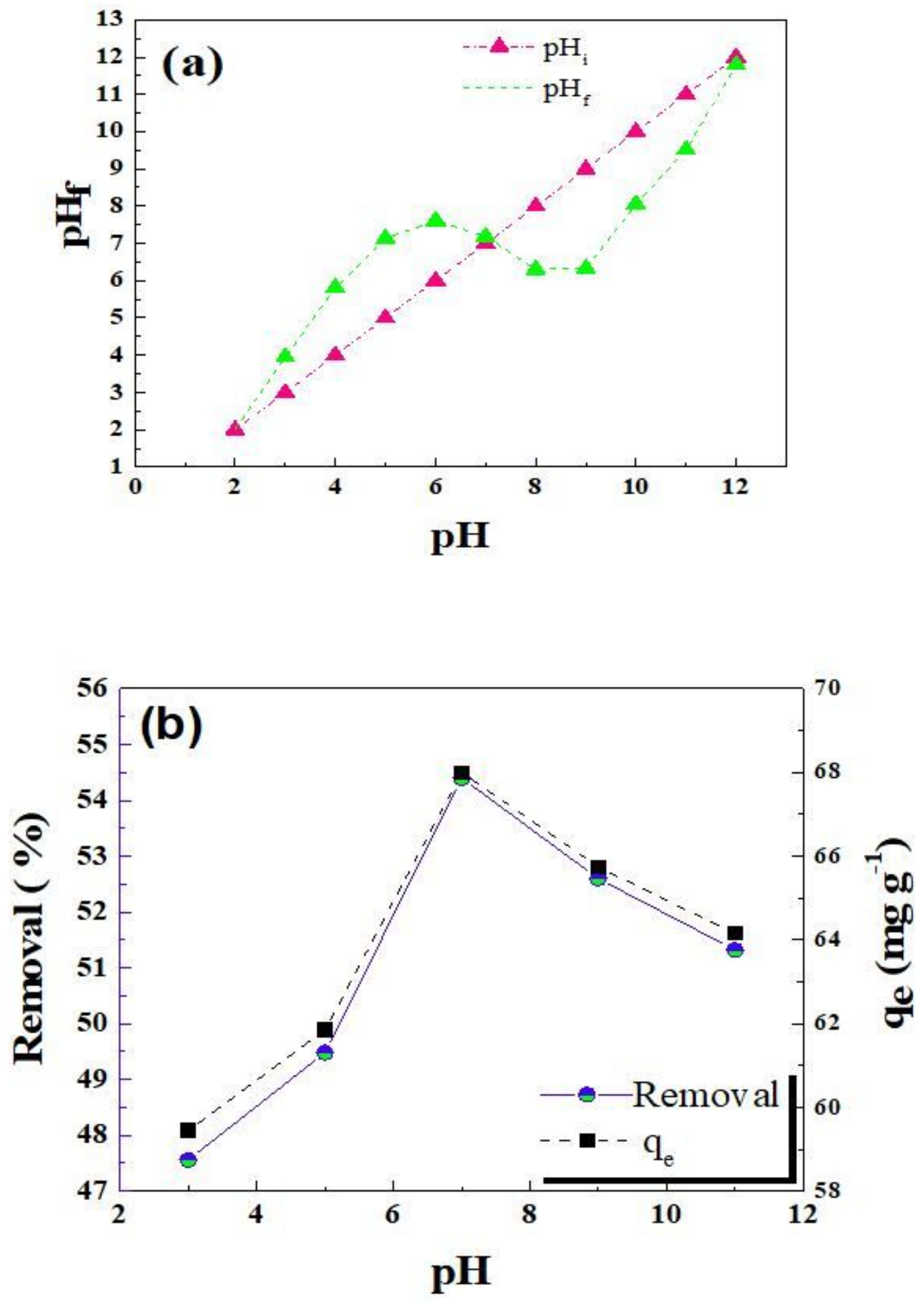

Figure 4

Effect $\mathrm{pH}$ improves on the efficiency of removal of furfural, pHpzc (a) and $\mathrm{pH}(\mathrm{b})(\mathrm{C} 0=200 \mathrm{mg} / \mathrm{L}, \mathrm{Tim}=60$ min, stirring speed $=250 \mathrm{rpm}$, Temp $=25 \pm 20 \mathrm{C}$ ). 


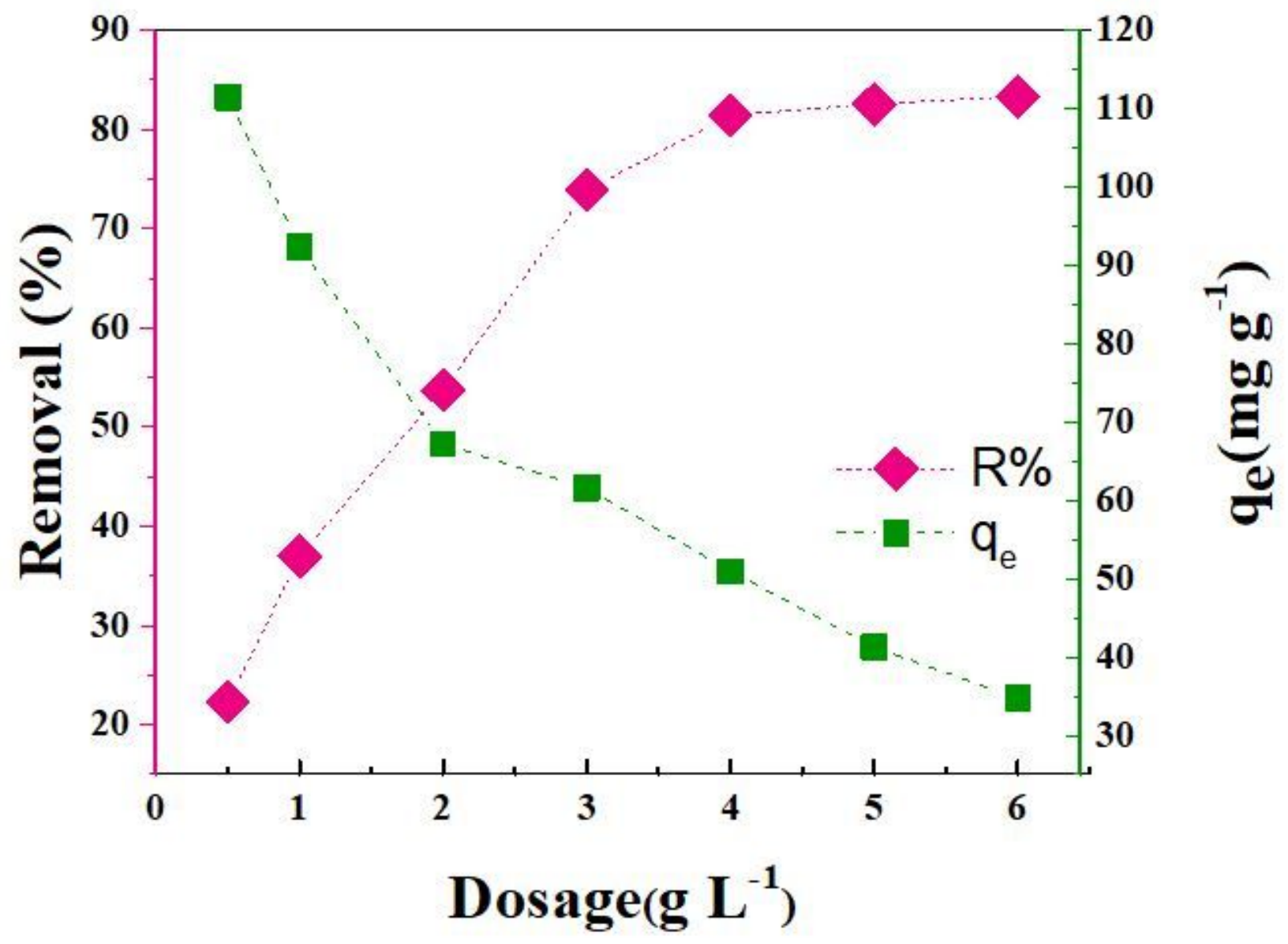

Figure 5

The effect of the AC-nZVI dosage varies on the removal efficiency of furfural ( $C 0=200 \mathrm{mg} / \mathrm{L}$, Tim=60 min, stirring speed $=250 \mathrm{rpm}, \mathrm{Temp}=25 \pm 2 \varangle \mathrm{C}$ and $\mathrm{pH}=7$ ). 


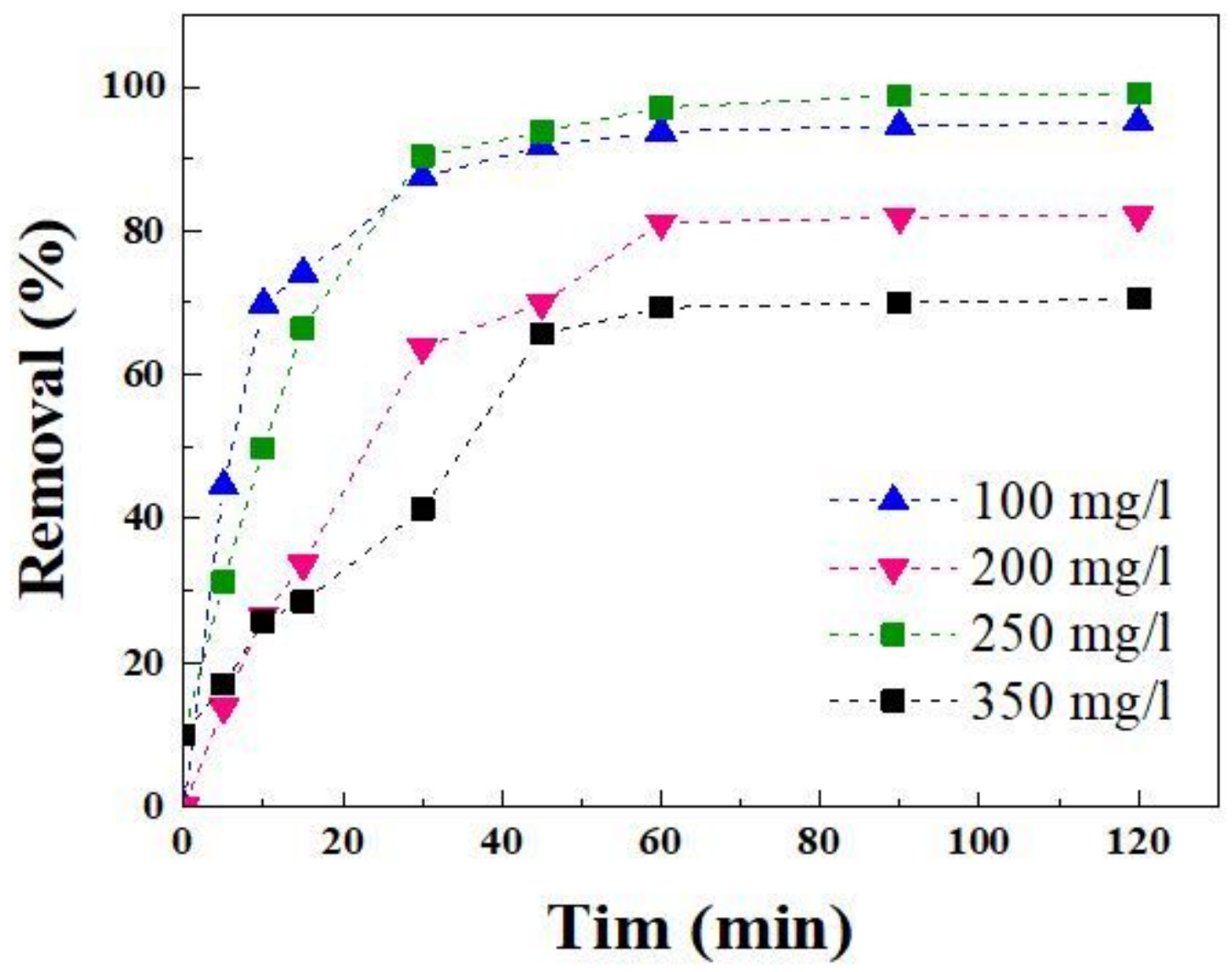

Figure 6

Effect of contact time and initial furfural Concentration for the adsorption of furfural onto AC-nZVI-NPs (dose $=4 \mathrm{~g} / \mathrm{L}$, stirring speed $=250 \mathrm{rpm}, \mathrm{Temp}=25 \pm 2 \bowtie \mathrm{C}$ and $\mathrm{pH}=7$ ). 

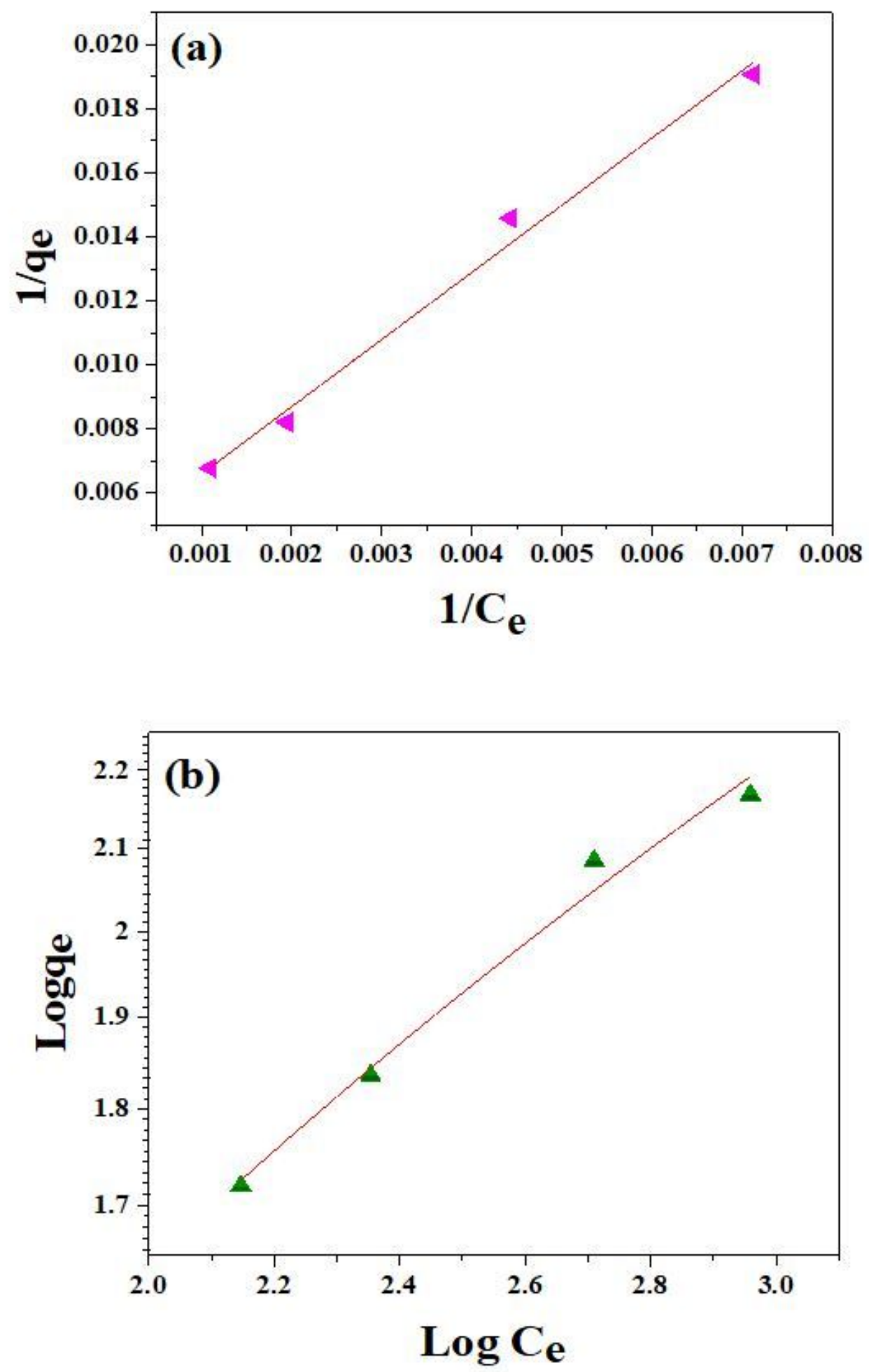

Figure 7

Langmuir (a) andFreundlich (b) models for adsorption of furfural by AC-nZVI-NPs. 


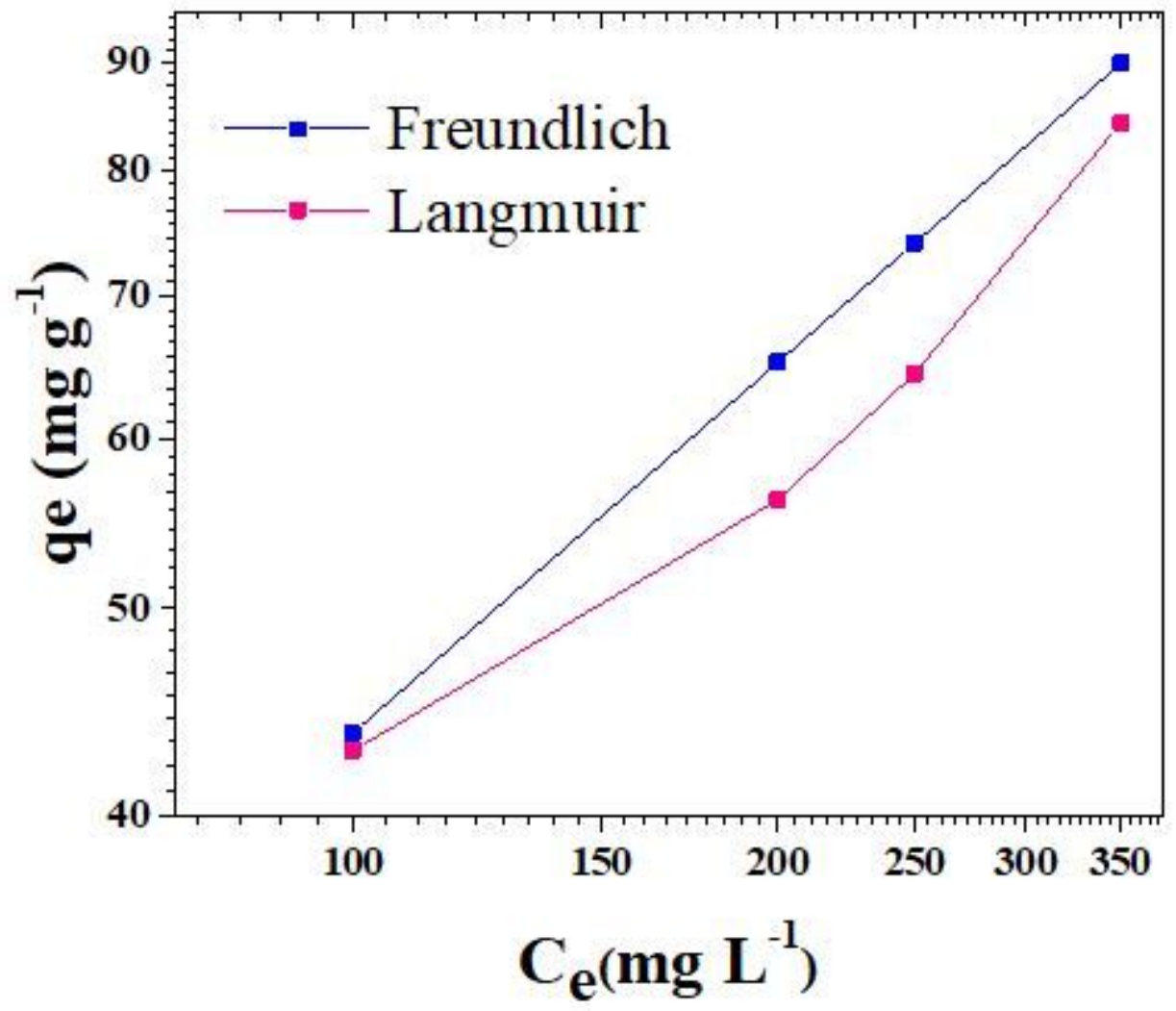

Figure 8

Isotherm plots for furfuraladsorption by AC-nZVI-NPs ( $\mathrm{pH}=7$, dose $=4 \mathrm{~g} / \mathrm{L}, \mathrm{C}=250 \mathrm{mg} / \mathrm{L}, \mathrm{Tim}=60 \mathrm{~min}$ stirring speed $=250 \mathrm{rpm}$ and Temp $=25 \pm 2 \llbracket \mathrm{C}$ ). 

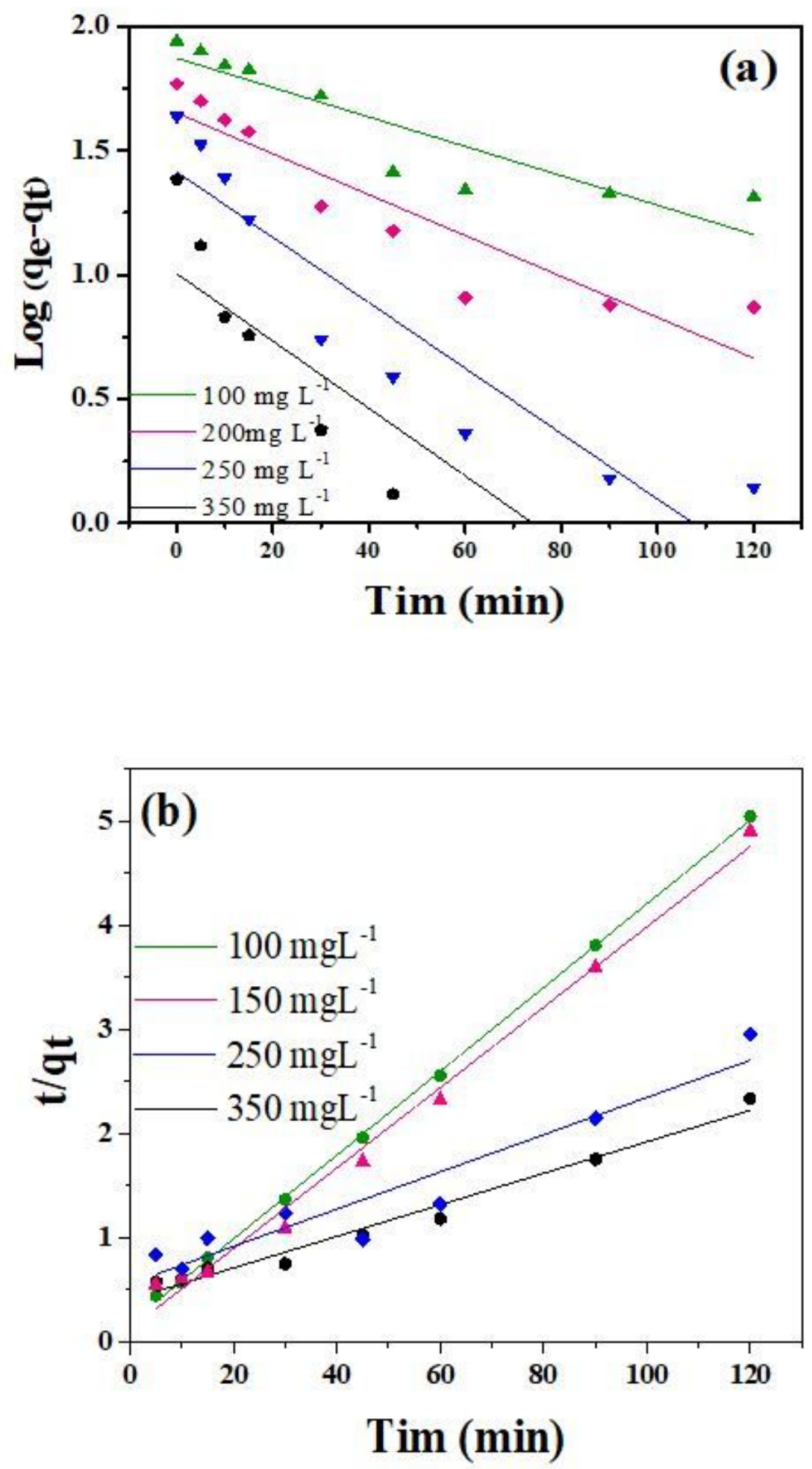

Figure 9

Pseudo first order (A) and second-order (B) kinetics models for the adsorption of furfuralby AC-nZVI-NPs. 


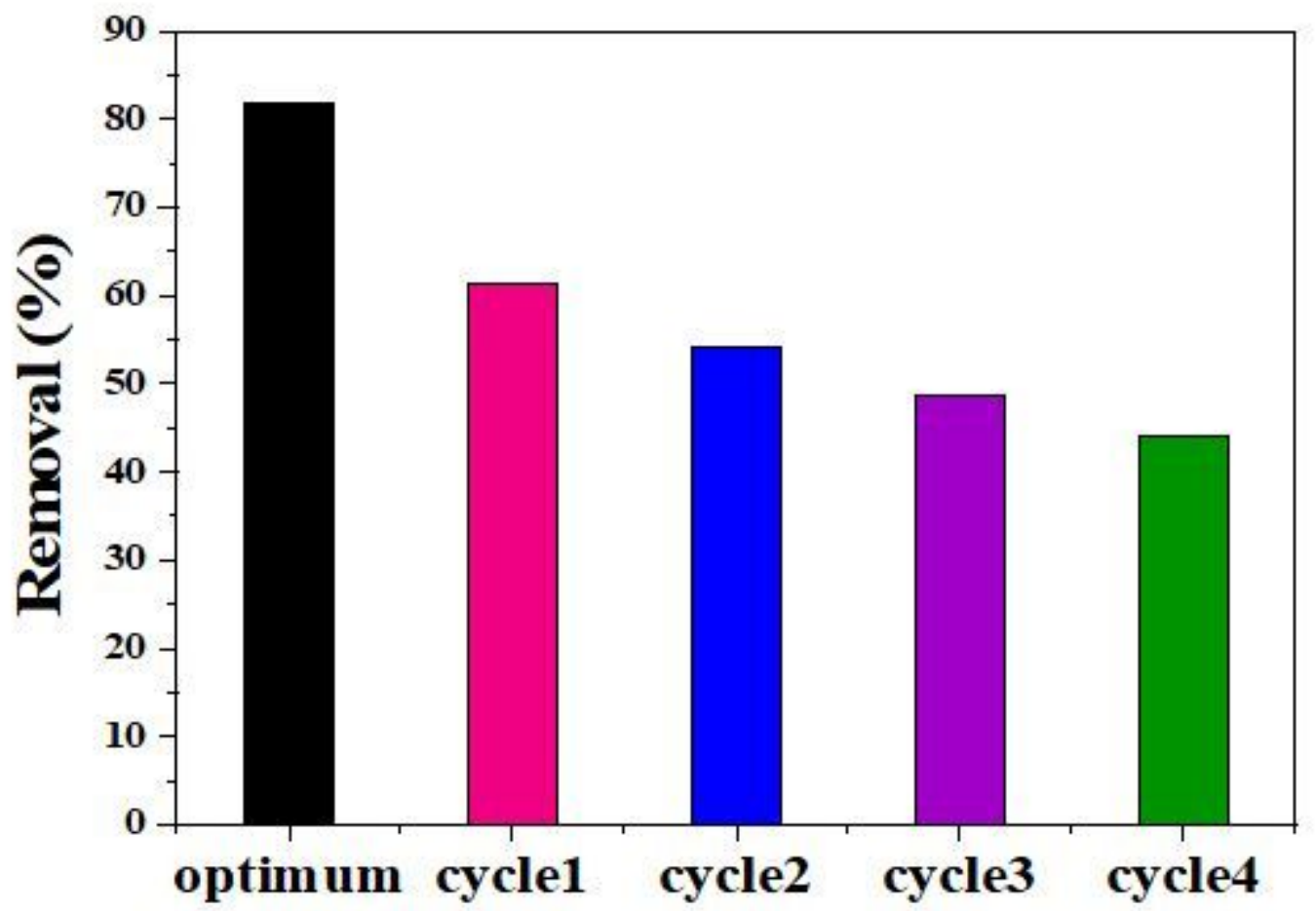

Figure 10

The AC-nZVI-NPs recovery in four stages. 


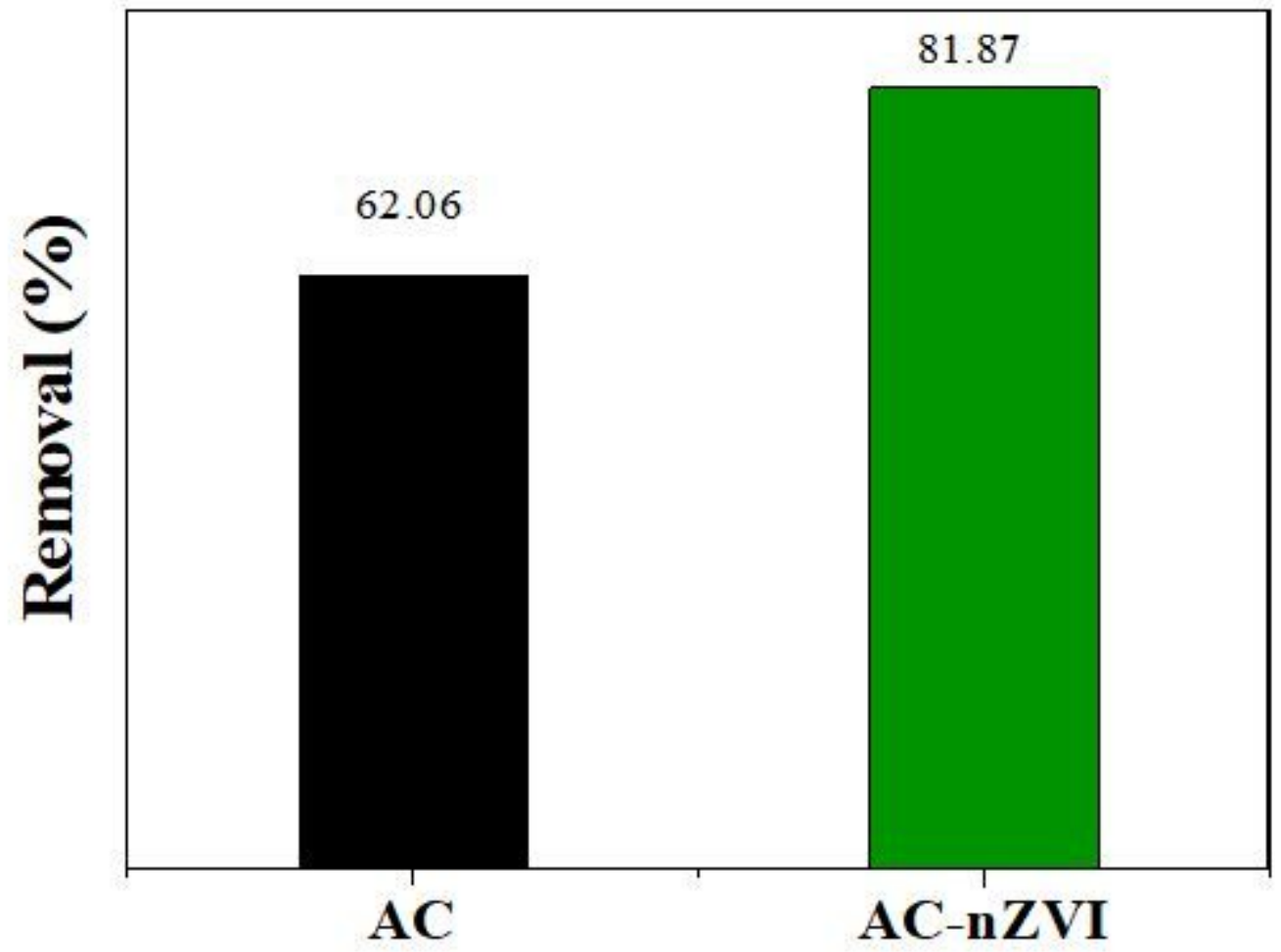

Figure 11

Comparison of different processes on the adsorption of furfural $(\mathrm{pH}=7$, dose $=4 \mathrm{~g} / \mathrm{L}, \mathrm{CO}=250$ $\mathrm{mg} / \mathrm{L}, \mathrm{Tim}=60 \mathrm{~min}$, stirring speed $=250 \mathrm{rpm}$ and $\mathrm{Tem}=25 \pm 20 \mathrm{C}$ ). 